\title{
Predicted distribution of whales at risk: identifying priority areas to enhance cetacean monitoring in the Northwest Atlantic Ocean
}

\author{
Catalina Gomez ${ }^{1,2, *}$, Jack Lawson ${ }^{1}$, Amy-Lee Kouwenberg ${ }^{1}$, Hilary Moors-Murphy ${ }^{2}$, \\ Alejandro Buren ${ }^{1}$, César Fuentes-Yaco ${ }^{2}$, Emma Marotte $^{2}$, Yolanda F. Wiersma ${ }^{3}$, \\ Tonya Wimmer ${ }^{4}$ \\ ${ }^{1}$ Marine Mammal Section, Northwest Atlantic Fisheries Centre, Department of Fisheries and Oceans, St. John's, \\ Newfoundland and Labrador A1C 5X1, Canada \\ ${ }^{2}$ Ocean and Ecosystem Sciences Division, Bedford Institute of Oceanography, Department of Fisheries and Oceans, \\ Dartmouth, Nova Scotia B2Y 4A2, Canada \\ ${ }^{3}$ Department of Biology, Memorial University of Newfoundland, St. John's, Newfoundland and Labrador A1B 3X9, Canada \\ ${ }^{4}$ Department of Biology, Dalhousie University, Halifax, Nova Scotia B3H 4R2, Canada
}

\begin{abstract}
Using long-term data from government, non-government, academic, and industry sources, we developed species distribution models (SDMs) to predict priority areas in which to target and enhance blue whale Balaenoptera musculus and northern bottlenose whale Hyperoodon ampullatus monitoring efforts in eastern Canada. Priority areas for blue whales were located primarily on the Scotian Shelf and along the south shelf break in waters off Newfoundland. Priority areas for northern bottlenose whales were identified primarily in areas along the edges of the eastern Scotian Shelf and the Newfoundland and Labrador Shelves, in submarine canyons, and deep basins. The SDM results and the tools presented in this study indicate that there are few conservation areas in eastern Canada that currently protect whales at risk, and that priority areas for blue and northern bottlenose whales overlap with regions where noise-producing activities (shipping and seismic exploration) occur. This study also highlighted large gaps in the cetacean data related to human activities (e.g. seismic survey lines are outdated and recent information from the past 5 to $10 \mathrm{yr}$ is not available). The SDM approach developed in this study can be used as an iterative, adaptive process by including updated data as it becomes available, further refining and validating the SDM results and thereby improve our understanding of the distribution of cetaceans and noise-producing activities in eastern Canada.
\end{abstract}

KEY WORDS: Species distribution model $\cdot$ Cetacean $\cdot$ Blue whale $\cdot$ Northern bottlenose whale . Canada $\cdot$ Spatial planning $\cdot$ MaxEnt

\section{INTRODUCTION}

The Northwest Atlantic Ocean (NWAO) is a productive ecosystem that supports breeding, feeding, and migratory habitats for a diverse assemblage of marine life (e.g. DFO 1998, Pepin et al. 2007). This region also supports a significant number of human activities that have varying effects on the ecology

${ }^{*}$ Corresponding author: catalina.gomez@dfo-mpo.gc.ca of the NWAO, including commercial shipping, fishing, and oil and gas exploration and production. As one example of an ecological impact of human activities, over-fishing has resulted in the depletion of fish stocks and has caused changes in the trophic structure and function of the NWAO (Fogarty \& Murawski 1998, Worm \& Myers 2003, Buren et al. 2014).

(C) The authors and Fisheries and Oceans Canada 2017. Open Access under Creative Commons by Attribution Licence. Use, distribution and reproduction are unrestricted. Authors and original publication must be credited.

Publisher: Inter-Research · www.int-res.com 
Whaling activities between the late 1800s and mid1900s have resulted in reduced populations of many marine mammal species, including the endangered blue whale Balaenoptera musculus and northern bottlenose whale Hyperoodon ampullatus. In eastern Canadian waters, approximately 1500 blue whales were killed by the Canadian whaling industry between 1898 and 1915 (see Beauchamp et al. 2009 and references therein), and about 905 northern bottlenose whales were killed between 1962 and 1971 (see a review in Reeves et al. 1993). Hunting of blue whales was prohibited by the International Whaling Commission in 1966, and northern bottlenose whales were listed as a protected species in 1977 in the schedule of the International Convention for the Regulation of Whaling (Reeves et al. 1993, Beauchamp et al. 2009). All commercial whaling activities ceased in Canada in 1974.

Currently, the Northwest Atlantic blue whale population likely numbers in the 100s of individuals (Sears \& Calambokidis 2002). Despite a ban on whaling, the population suffers from low calving and recruitment rates (COSEWIC 2002, Beauchamp et al. 2009). In addition to residual impacts of whaling on this population, 40 blue whales have been killed by ice entrapments since 1974. The most recent entrapment occurred off the west coast of Newfoundland in 2014, and resulted in the death of 9 blue whales. These recent entrapments represent a significant loss to the blue whale breeding population in the NWAO and highlight that natural processes also threaten the recovery of this population.

Little is known about the abundance of northern bottlenose whales in the NWAO, with the exception of a small resident population that primarily inhabits the submarine canyons of the eastern Scotian Shelf off Nova Scotia (e.g. Gowans et al. 2000). This 'Scotian Shelf' population, comprised of less than 150 animals, has been relatively stable since studies began in the 1980s (O'Brien \& Whitehead 2013) and is managed as a distinct population that is genetically different from another northern bottlenose whale population located further north off the Labrador Peninsula (the 'Davis Strait-Baffin Bay-Labrador Sea' population) (Dalebout et al. 2001, 2006).

Due to their small population sizes and the increasing number of human activities in the NWAO that may impact them, both the Northwest Atlantic blue whale population and the Scotian Shelf northern bottlenose whale population are listed as endangered under the Canadian Species at Risk Act (SARA) (Government of Canada 2005, 2006). Due to the historical impacts of whaling and current threats from fishery interactions, the Davis Strait-Baffin BayLabrador Sea northern bottlenose whale population has been listed as special concern by COSEWIC (2011). For all 3 of these whale populations, ship strikes, entanglement in fishing gear, and noise generated from human activities are considered important threats (e.g. COSEWIC 2002, 2011, Beauchamp et al. 2009, Vanderlaan et al. 2011, DFO 2016).

Information on the distribution of and important habitat for species at risk is essential to direct conservation efforts to mitigate threats that may be impeding recovery (Roberts et al. 2016). A requirement under SARA is that critical habitat ${ }^{\underline{1}}$ of endangered and threatened species must be identified and protected (SARA 2002). Critical habitat for the Northwest Atlantic blue whale population has not yet been identified (Beauchamp et al. 2009), whereas 3 submarine canyons in the eastern Scotian Shelf (The Gully, Shortland, and Haldimand) have been identified as critical habitat for the Scotian Shelf population of northern bottlenose whales (DFO 2009, 2016, Government of Canada 2010). Furthermore, Section 32 of the SARA (SARA 2002, p. 18) states that

\begin{abstract}
No person shall kill, harm, harass, capture or take an individual of a wildlife species that is listed as an extirpated species, an endangered species or a threatened species
\end{abstract}

\section{Section 58 (SARA 2002, p. 29) states that}

no person shall destroy any part of the critical habitat of any listed endangered species or of any listed threatened species.

Thus, threats directly or indirectly causing such harm and harassment must be identified so that they can be eliminated or adequately reduced. In this context, there is pressing need to increase our understanding of the seasonal distribution and critical habitat of these species at risk (Beauchamp et al. 2009, DFO 2009, 2014, 2016).

Cetacean effort-based surveys (e.g. line-transect surveys) have been conducted in only a quarter of the world's oceans (Kaschner et al. 2012) and thus knowledge of cetacean seasonal distribution, density, and critical habitat is generally limited. While cetacean effort-based surveys in the Canadian NWAO are also limited (e.g. Breeze et al. 2002, Lawson \& Gosselin 2009), there are a large number of cetacean sighting records from opportunistic platforms (e.g. Gomez \& Moors-Murphy 2014). These

\footnotetext{
$\underline{1}$ Under the Canadian Species at Risk Act, critical habitat is defined as 'the habitat that is necessary for the survival and recovery of a listed wildlife species', and the destruction of critical habitat is prohibited (SARA 2002)
} 
reflect presence-only records, which, together with readily available and broad-scale environmental data, provide an opportunity to improve our knowledge of the distribution of blue and northern bottlenose whales at risk using species distribution modelling (SDM) (Elith et al. 2011, Merow et al. 2013). SDM is a valuable tool for predicting the distribution of species which can then be used to inform management initiatives. For example, identifying critical habitat and ecological hotspots using SDM can help in the planning of marine protected area (MPA) networks, including those designed primarily for the conservation of predators (Gregr \& Trites 2001, Cañadas et al. 2005, Hooker et al. 2011, Horsman et al. 2011). Furthermore, both regulators and industry require information on the distributions of species at risk to accurately assess and mitigate impacts from current and proposed human activities (Nowacek et al. 2013, 2015, Wright 2014, Wright \& Kyhn 2015). To that end, SDM has been used as a planning tool for minimizing impacts of seismic activities on whale populations (Bombosch et al. 2014).

Recognizing the strengths and limitations of presence-only SDM approaches (Merow et al. 2013), we investigated areas in which to prioritize monitoring blue and northern bottlenose whales, as these areas appear to contain potentially high and moderate suitable habitat. Furthermore, we propose a framework to use and update the datasets and methods provided here as part of an iterative, adaptive process to monitor the distribution of whales at risk in eastern Cana$\mathrm{da}$, validate the SDM results presented here, and ultimately contribute to the marine spatial process currently underway in the region (Government of Canada 2011, King et al. 2013, Westhead et al. 2013).

\section{MATERIALS AND METHODS}

\section{NWAO study area}

The study area is situated in the Northwest Atlantic, encompassing waters of the provinces of Nova Scotia and Newfoundland and Labrador in eastern Canada. The NWAO comprises a continental shelf of varying breadth, characterized by a complex topography of shallow banks, basins, and submarine canyons, and bounded by convoluted coastlines and deep ocean basins (Breeze et al. 2002, Zwanenburg et al. 2002). In the present study, the NWAO was delineated in the north by the northern tip of Labrador and in the south by the Fundian (or Northeast) Channel (Fig. 1). The Gulf of St. Lawrence and the inner portion of the Bay of Fundy, which are characterized by very different ecosystem dynamics compared with the rest of the NWAO (Therriault 1991, Zwanenburg et al. 2002, Araújo \& Bundy 2012), were not considered here.

\section{Cetacean data}

We capitalized on long-term cetacean sightings data available from the Department of Fisheries and Oceans (DFO), the Ocean Biogeographic Information System (OBIS), the North Atlantic Right Whale Consortium (NARWC), the Whitehead lab at Dalhousie University (http://whitelab.biology.dal.ca/), and Environment Canada's (Canadian Wildlife Service) Eastern Canada Seabirds at Sea (ECSAS) programme. Data from DFO (such as www.inter.dfo-mpo.gc.ca/ Maritimes/SABS/popec/sara/Database), OBIS (www. iobis.org/), and the NARWC (www.narwc.org/) are compilations of sightings from a variety of sources including aerial and vessel-based surveys conducted by industry, academic, government, and non-government organizations. Locations of cetacean sightings from all sources were merged and yielded 120789 records after data quality control checks were performed; these checks included discarding records outside of our study area and removing redundant records (same species, day, month, latitude and longitude). Records included in the dataset were obtained during the whaling (sightings or catches prior to 1975 ; $\mathrm{n}=8873$ records) and post-whaling periods (freeswimming whales, 1975 to $2015 ; \mathrm{n}=111916$ ). The dataset used in this study did not include strandings/ dead animals or entrapment data.

Less than $1 \%$ of all cetacean sighting records were blue whales $(n=624)$. Records of blue whales prior to 1975 corresponded to individuals killed or sighted during the whaling period on the western Scotian Shelf and off southwest Newfoundland $(n=304)$. The majority of blue whale records during the post-whaling period $(\mathrm{n}=320)$ were obtained during the summer (June to August; $\mathrm{n}=222$ ), followed by fall (September to November; $\mathrm{n}=52$ ), spring (March to May; $\mathrm{n}=36$ ), and winter (December to February; $\mathrm{n}=10$ ).

Only $2 \%$ of the cetacean sighting records were northern bottlenose whales $(n=2803)$. Records of sightings and kills of this species during the whaling period prior to 1975 were from the Scotian Shelf region only $(n=33)$. The majority of the northern bottlenose whale records were live individuals sighted after the whaling period $(\mathrm{n}=2770)$ and observed during the summer $(\mathrm{n}=2366)$, followed by spring $(\mathrm{n}=$ $205)$, fall $(\mathrm{n}=171)$, and winter $(\mathrm{n}=28)$. 

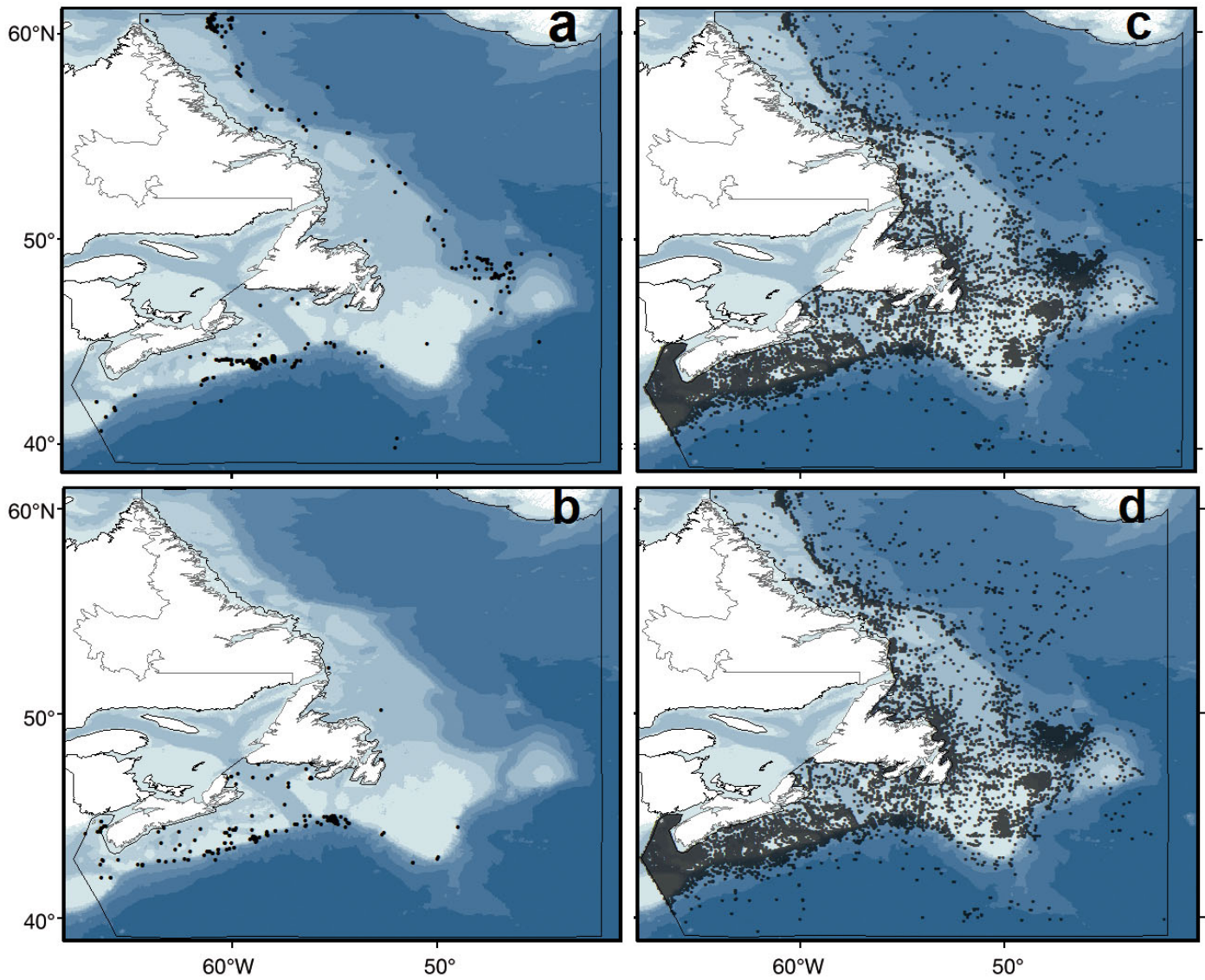

Fig. 1. Sightings (black dots) collected within the boundaries of our study area (black line) of (a) northern bottlenose whales Hyperoodon ampullatus ( $\mathrm{n}=2366)$, (b) blue whales Balaenoptera musculus $(\mathrm{n}=222)$, and records (grey dots) of cetacean species (c) other than northern bottlenose whales (74 466) and (d) other than blue whales (76 610). Cetacean records were gathered from the Department of Fisheries and Oceans, the Ocean Biogeographic Information System, the North Atlantic Right Whale Consortium, the Whitehead lab at Dalhousie University, and the Eastern Canada Seabirds at Sea programme

Fewer cetacean sightings were recorded in winter, spring, and fall - likely due to unfavourable weather and greatly reduced visual effort in these seasons compared to summer. Consequently, we only used records of live blue and northern bottlenose whales observed in the summer post-whaling period (June to August; 1975 to 2015) to construct the SDMs (Fig. 1).

\section{Environmental data}

A fundamental component of SDM is the selection of a suite of environmental variables that exhibit a spatial and temporal relationship with the location records for the species of interest, and thus, are useful to predict priority areas. Information on the prey of the species of interest is an ideal predictor variable (e.g. Pendleton et al. 2012); however, there is a lack of information on the spatial and temporal distribution of the prey of blue whales (euphausiids) and northern bottlenose whales (e.g. squid Gonatus spp.). Consequently, the relationship between whales and their prey was not integrated directly. Instead, we employed an approach similar to previous studies with limited prey data that used environmental variables as proxies for prey availability (e.g. Gregr 2011, Roberts et al. 2016) (Table 1): (1) ocean depth (Fig. 2); (2) compound topographic index (CTI) - derived from ocean depth (Evans et al. 2014), this variable reflects the peaks (high numeric values of CTI), basins (low values), and flat surfaces (intermediate values) of the ocean floor (Moore et al. 1991, Gessler et al. 1995, Andersen et al. 2013) (Fig. 2); (3) sea surface temperature (SST) - average summer water temperature close to the ocean's surface (Fig. 2); (4) areas of persistently high chlorophyll a ( $\mathrm{chl}$ a) concentration (Fig. 3). Every pixel in the weekly composite satellite images was compared against a specific threshold value represented by its own median plus a half standard deviation. Pixels above the threshold are 
Table 1. Environmental layers used to predict the distribution of blue Balaenoptera musculus and northern bottlenose whales Hyperoodon ampullatus in the Northwest Atlantic Ocean. Seasons for variables that have a temporal resolution corresponded to spring (March to May) and summer (June to August). SDM: species distribution modelling; na: not applicable

\begin{tabular}{|c|c|c|c|}
\hline Ocean depth (m) & Static variable & $1 \mathrm{~km}$ & $\begin{array}{l}\text { Oceans and Coastal Management Division, Mari- } \\
\text { times Region, Department of Fisheries and Oceans, } \\
\text { Bedford Institute of Oceanography }\end{array}$ \\
\hline Compound topographic (CTI) (na) & Static variable & $1 \mathrm{~km}$ & $\begin{array}{l}\text { Calculated using the Geomorphometry index and } \\
\text { Gradient Metrics Toolbox version } 2.0 \text { in ArcGIS } \\
\text { (Evans et al. 2014) }\end{array}$ \\
\hline Sea surface temperature (SST) $\left({ }^{\circ} \mathrm{C}\right)$ & $\begin{array}{l}\text { Seasonal (summer month } \\
\text { values used in SDM) }\end{array}$ & $\begin{array}{c}1.5 \mathrm{~km} \\
\text { pixel }\end{array}$ & $\begin{array}{l}\text { Derived from images obtained from the Moderate } \\
\text { Resolution Imaging Spectroradiometer (MODIS) } \\
\text { instrument on the Aqua satellite. The seasonal } \\
\text { climatologies were derived from semi-monthly } \\
\text { composites for 2003-2014. (www.bio-iob.gc.ca/ } \\
\text { science/newtech-technouvelles/sensing-teledetect } \\
\text { ion/index-en.php) }\end{array}$ \\
\hline
\end{tabular}

termed transformed chlorophyll indicators (for detailed description of the methods, see Fuentes-Yaco et al. 2015); and (5) regional chl a magnitude (Fig. 3) (Fuentes-Yaco et al. 2015), representing the central tendency of chl a concentration $\left(\mathrm{mg} \mathrm{m}^{-3}\right)$. This predictor was calculated by obtaining the median chl a concentration values for each pixel, and then averaging those medians over the 4 sub-regions described below.

The latter 2 environmental variables were derived by identifying and mapping phytoplankton-rich zones using satellite imagery to provide an indication of primary producers (Table 1). The procedures used to develop each of these maps are presented in detail in Fuentes-Yaco et al. (2015), and summarized briefly here. The study area was first subdivided into neritic (50 to $600 \mathrm{~m}$ depth) and oceanic (>600 m depth) regions. These regions were further subdivided into north and south sections following the boundaries of Divisions 3 and 4 of the Northwest Atlantic Fisheries Organization (NAFO; Fig. 3) as well as distinct bathymetric and hydrographic features. Each of these 4 large geographical regions has unique marine communities and food web systems (Devred et al. 2007, 2009, Longhurst 2007, NAFO 2014). For each of the regions, we computed the relative contribution (\%) of persistently high chl a (hereafter referred to as $\mathrm{CHL}_{\text {pers }}$ ) and the average of the median chl a concentration $\left(\mathrm{mg} \mathrm{m}^{-3}\right.$, hereafter referred to as $\left.\mathrm{CHL}_{\text {magn }}\right)$ (Fig. 3). The goal of separating the study area into sub-regions was to characterize chlorophyll predictors for cetacean habitat in relation to relative primary producers. $\mathrm{CHL}_{\text {magn }}$ allowed us to distinguish the central tendencies of $\mathrm{chl}$ a concentration values per sub-region. For example, such delineation helps illustrate that oceanic regions of this study area have relatively lower chl a values compared with neritic zones (Fig. 3). Consequently, Fuentes-Yaco et al. (2015) proposed that each sub-region should be analysed independently to avoid the 'statistical attraction' of pixels in regions with very high concentrations of chlorophyll (e.g. neritic south) when compared to pixels in areas of low concentration of pigments (e.g. oceanic south). Areas of low yet persistent concentration of pigments could be particularly important for whales and their prey. In fact, previous studies using a different approach have found that shelf edges (areas of low concentration of pigments) are important habitat for a wide number of species, including beaked and baleen whales (e.g. Whitehead 2013, Gomez \& Moors-Murphy 2014; see Moors-Murphy 2014 for a review). If the sub-regions are not considered in the calculation of $\mathrm{chl}$ a persistence, the shelf edges appear as 'oceanic desert' areas, when in reality this not likely the case (Grant et al. 1987).

Seasonal climatologies of $\mathrm{CHL}_{\text {pers }}$ as well as $\mathrm{CHL}_{\text {magn }}$ for spring (March to May) and summer (June to August), were derived from weekly composites between 2003 and 2014 (Fig. 3, Table 1). Sum- 

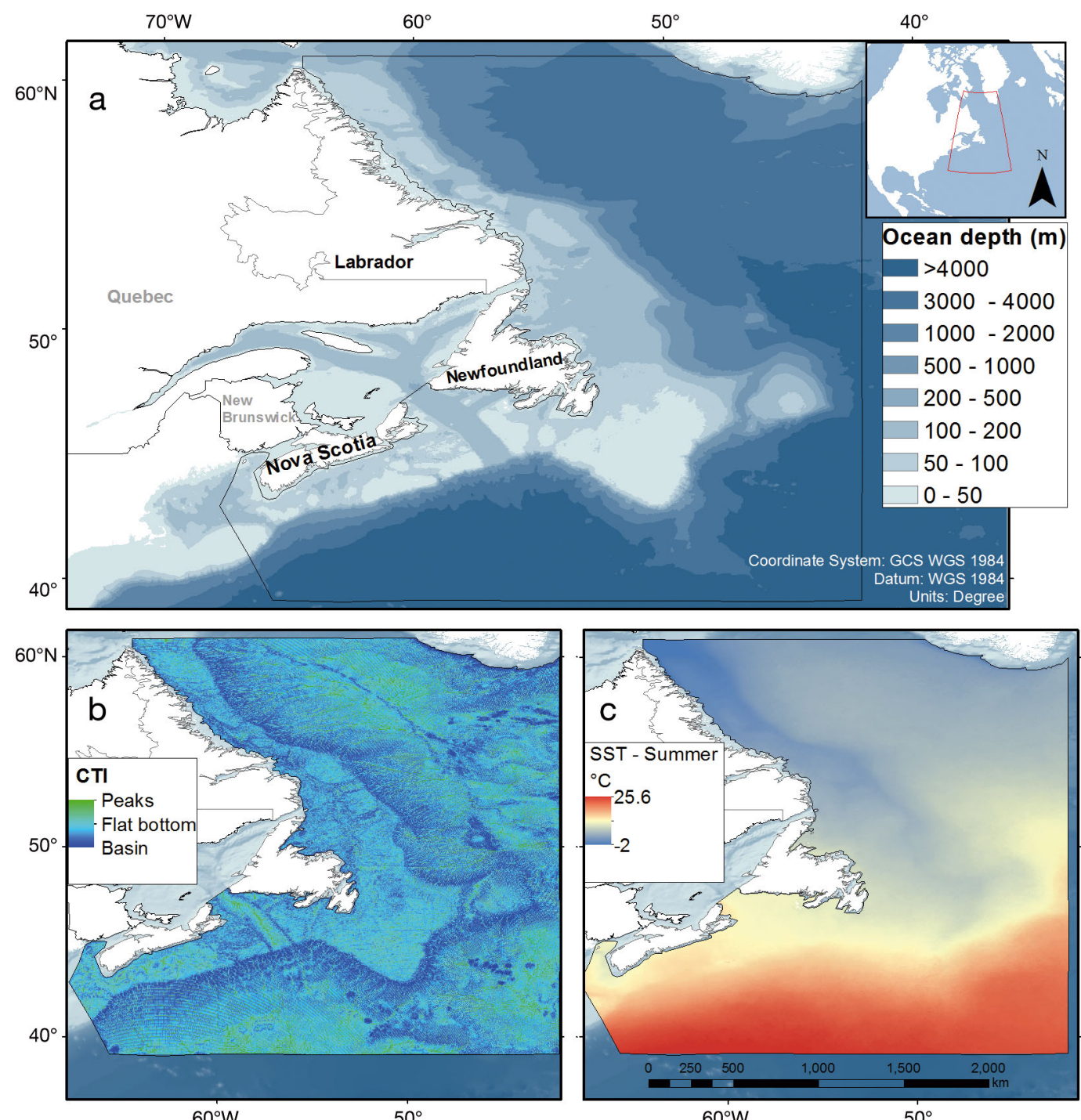

Fig. 2. Physical environmental data used to predict the distribution of blue Balaenoptera musculus and northern bottlenose whales Hyperoodon ampullatus in the Northwest Atlantic Ocean: (a) ocean depth (m), (b) compound topographic index (CTI), and (c) sea surface temperature ( $\mathrm{SST}_{;}{ }^{\circ} \mathrm{C}$ ) during the summer (June to August). CTI, derived from ocean depth, is a continuous variable that ranged from 9.57 to 27.8 (low values represent basins, high values represent peaks, and intermediate values around 18.7 represent flat surfaces). Seasonal climatologies for SST were derived from semi-monthly composites for the 2003 to 2014 period

mary maps of these values were produced for 2 seasons: summer (the time at which locations of cetaceans were gathered for the SDM) and spring (to account for the time-lag needed for primary producers to transfer to secondary producers; Jaquet 1996, Croll et al. 2005, Wong 2012). Importantly, shallow coastal areas in the ocean typically contain a mixture of constituents with different optical properties, such as phytoplankton, other suspended particulates, and yellow substances (Morel \& Prieur 1977). In addition, shallow waters are also influenced by the depth of the water column, and by the nature of the bottom. Consequently, these areas require detailed and cus- tomized algorithms to identify concentrations of chl a (IOCCG 2000). This evaluation was not applied in this study, thus shallow coastal areas $<50 \mathrm{~m}$ depth were excluded from the analyses.

All environmental layers were processed to have the same geographic extent, projection system (World geodetic System [WGS] 1984), and cell size $(1.5 \mathrm{~km})$, then converted to an ASCII raster grid format using ArcGIS 10 (Evans et al. 2014). The variance inflation factor (VIF; Zuur et al. 2010) was used to investigate collinearity between environmental variables. Note that the average regional chl a magnitude was not included in the VIF calculations as it 

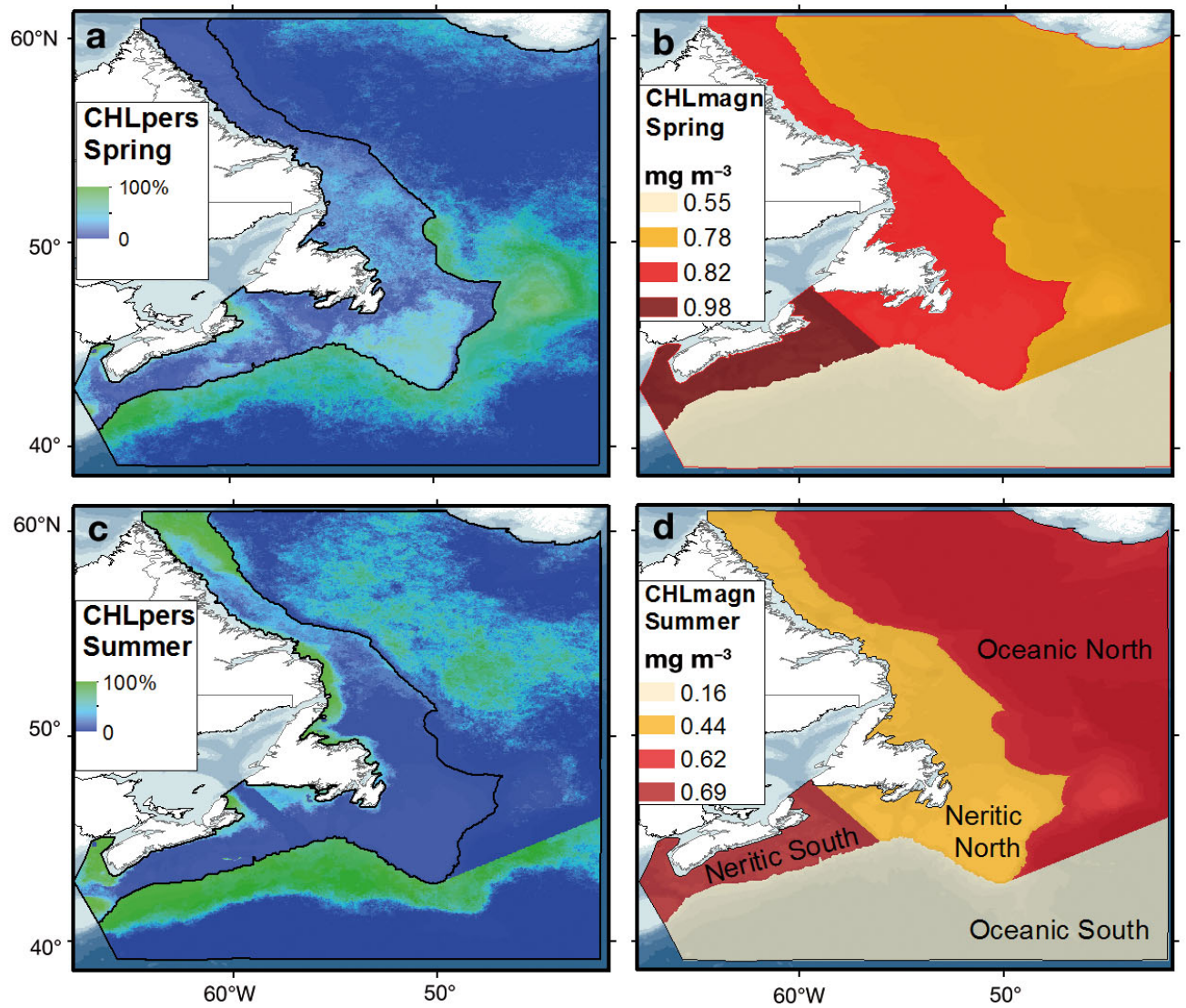

Fig. 3. Biological environmental data used to predict the distribution of blue Balaenoptera musculus and northern bottlenose whales Hyperoodon ampullatus in the Northwest Atlantic Ocean: areas of $(\mathrm{a}, \mathrm{c})$ persistently high chl a concentration $\left(\mathrm{CHL}_{\mathrm{pers}}\right)$ and $(\mathrm{b}, \mathrm{d})$ average regional chl a magnitude $\left(\mathrm{CHL}_{\text {magn }}\right)$. Seasonal climatologies (spring: March to May, and summer: June to August) were derived from weekly composites for the 2003 to 2014 period (Table 1 in Fuentes-Yaco et al. 2015). Black line: subdivision of the study area into neritic (between 50 and $600 \mathrm{~m}$ depth) and oceanic (>600 m depth). Neritic and oceanic regions were further divided into north and south (d)

is comprised of only 1 (average) value per unique region (Fig. 3). VIF values $<3$ denote that the environmental variables do not exhibit collinearity and thus are relevant to use in the SDM.

\section{SDM: identifying priority areas to enhance cetacean monitoring}

We used the software MaxEnt v.3.3.3k (Phillips et al. 2006) to build the SDM because this tool performs well compared to other approaches that also use species presence locations (data where associated effort is unavailable) and when sample size is relatively small (Elith et al. 2006, Pearson et al. 2007, Tittensor et al. 2009). This type of opportunistically collected data with a lack of true absence data (zeros) is commonly combined with MaxEnt to predict the distribution of whale species (e.g. Gregr 2011, Ainley et al. 2012, Pendleton et al. 2012, Bombosch et al. 2014).
MaxEnt incorporates the location of each species' presence (presence-only data) and a set of environmental data predictors across the area of study (landscape). MaxEnt then extracts a sample of locations of species presence and a sample of point locations within the landscape; these 2 locations are contrasted to explore the relative occurrence rate $\left(\mathrm{ROR}_{i}\right.$ Fithian $\&$ Hastie 2013). The ROR describes the relative probability of presence of the individual in the landscape (Phillips et al. 2006, Merow et al. 2013); MaxEnt's raw output is interpreted to be a ROR. To allow for comparisons between results for different species, we rescaled the raw output to range between 0 and 100 . We used this cumulative output to generate maps of priority areas to target future monitoring of blue and northern bottlenose whales. These maps were based on 4 arbitrary categories: high (100 to $60 \%$ ), moderate (60 to $40 \%$ ), low (40 to $10 \%$ ) and very low $(<10 \%)$ priority (e.g. Ananjeva et al. 2015). The MaxEnt run settings are provided in Table 2. 
Table 2. MaxEnt run settings used to build the species distribution model of blue whales Balaenoptera musculus and northern bottlenose whales Hyperoodon ampullatus in the Northwest Atlantic Ocean. Settings were selected following Phillips et al. (2006) and Merow et al. (2013)

\begin{tabular}{|c|c|c|}
\hline Variable & Setting & Comments \\
\hline Random seed & Yes & \\
\hline $\begin{array}{l}\text { Maximum number of } \\
\text { background points }\end{array}$ & 10000 & $\begin{array}{l}\text { A random sample of point locations from the landscape to represent the } \\
\text { environmental conditions in the study area }\end{array}$ \\
\hline Regularization multiplier & 1 & Included to reduce model over-fitting \\
\hline Output grids & None & \\
\hline Maximum iterations & 5000 & Allows the model to have adequate opportunity for convergence \\
\hline Convergence threshold & 0.00001 & \\
\hline Replicated run type & Cross-validate & $\begin{array}{l}\text { Assesses uncertainty in model predictions; it incorporates all available } \\
\text { sightings, making better use of smaller datasets. For this, occurrence data is } \\
\text { randomly split into a number of equally-sized groups (folds), and models are } \\
\text { created leaving out each fold in turn. These left-out folds are then used for } \\
\text { model evaluation }\end{array}$ \\
\hline Number of replicates & 100 & $\begin{array}{l}\text { Multiple runs for the same species. This allows averages of the results from } \\
\text { all models (number of replicates) created to be obtained; average values are } \\
\text { used to generate habitat suitability maps }\end{array}$ \\
\hline Output type & Cumulative & $\begin{array}{l}\text { Does not rely on post-processing assumptions and is useful when illustrating } \\
\text { potential species range boundaries }\end{array}$ \\
\hline $\begin{array}{l}\text { Alternate estimates of } \\
\text { variable importance }\end{array}$ & Jacknife & $\begin{array}{l}\text { Each predictor variable is excluded in turn, and a model is fitted with the } \\
\text { remaining variables. Then, a model is created using each variable in } \\
\text { isolation. In addition, models are created using all variables }\end{array}$ \\
\hline
\end{tabular}

\section{Evaluation of MaxEnt model performance}

The area under the curve (AUC) metric of the receiver operating characteristic (ROC) was used to evaluate the ability of the SDM to discriminate correctly between sites associated with the presence of whales and the sample of points from the landscape (Phillips et al. 2006). For this, we selected the crossvalidation option in MaxEnt as recommended in Merow et al. (2013) (Table 2) and used the AUC to investigate the probability that a randomly chosen whale presence location was ranked higher than a randomly chosen location in the landscape. An AUC value close to 1.0 indicates that the SDM has good discriminatory power, whereas a value $\leq 0.5$ indicates that the model prediction is no better than random (Fielding \& Bell 1997).

\section{Sampling bias correction}

Bias in the sampling effort within a study area can influence the reliability and quality of the SDM (Bystriakova et al. 2012, Fourcade et al. 2014). There are 2 types of sampling bias in this study: (1) whale records in areas of potential high and moderate priority may be absent due to lack of survey effort; and (2) whale records may be overrepresented in regions with high sampling efforts (e.g. the Gully MPA, outer Bay of Fundy). We applied 2 methods to account for this: bias file and sampling (Fourcade et al. 2014).

Bias file. Most whale sighting data gathered for this study were obtained from opportunistic surveys and thus do not contain a measure of survey effort. Sightings of cetacean species other than blue or northern bottlenose whales are available, and we term these 'non-target group species' (non-TGS). We created a sampling distribution bias map by plotting these nonTGS records within the study area. We considered cells that were within a given radius of a non-TGS record to be 'surveyed cells' and used these cells to generate a bias file which provided an a priori relative sampling probability (Phillips et al. 2006, Merow et al. 2013). We used summer non-TGS records for blue and northern bottlenose whales to generate bias maps that represent 'sampled' areas in the NWAO (Fig. 1). To explore how these bias maps impacted the SDM results, we ran the model with and without the bias file. We further refined this approach to assess the effect of the scale of the spatial search by adjusting the radius of the surveyed cells to 3 levels: $1,2.5$, and $5 \mathrm{~km}$.

Mixed random-systematic sampling of TGS records. MaxEnt discards redundant records that oc- 
cur in a single cell (records with the same geographic coordinates); however, it does not discard multiple records that can occur in neighbouring cells and thus may over-represent regions with high sampling efforts (Kadmon et al. 2004). To reduce the spatial aggregation of records in neighbouring cells, we randomly sub-sampled 1 whale sighting on a predetermined grid (Fourcade et al. 2014). To explore how the size of the grids might impact the SDM results, we conducted this sub-sampling at 3 different spatial resolutions: $1,2.5$, and $5 \mathrm{~km}$. In this way, we used 4 datasets for each species to model their priority areas: not sampled, and sampled at 1, 2.5 and $5 \mathrm{~km}$ spatial resolutions.

Effect of sampling bias correction in the SDM. For each dataset (4) per species, we ran the SDM with and without the bias files $(4)$, leading to $16(4 \times 4)$ sce- narios of predicted priority areas per species. We obtained the Pearson's rank correlation coefficient (r) between these predicted maps of priority areas (Quinn \& Keough 2002) to investigate how the model results were altered under each scenario of sampling bias correction. A summary of the SDM methodology employed in the study is provided in Fig. 4.

\section{Mapping conservation areas and human activities (shipping and seismic surveys) in the NWAO}

A key part of systematic conservation planning is revisiting the efficacy of existing area-based protection measures in light of new information on species distribution (Margules \& Pressey 2000, Tognelli et al. 2008, 2009, Wiersma \& Nudds 2009, Sharafi et al.

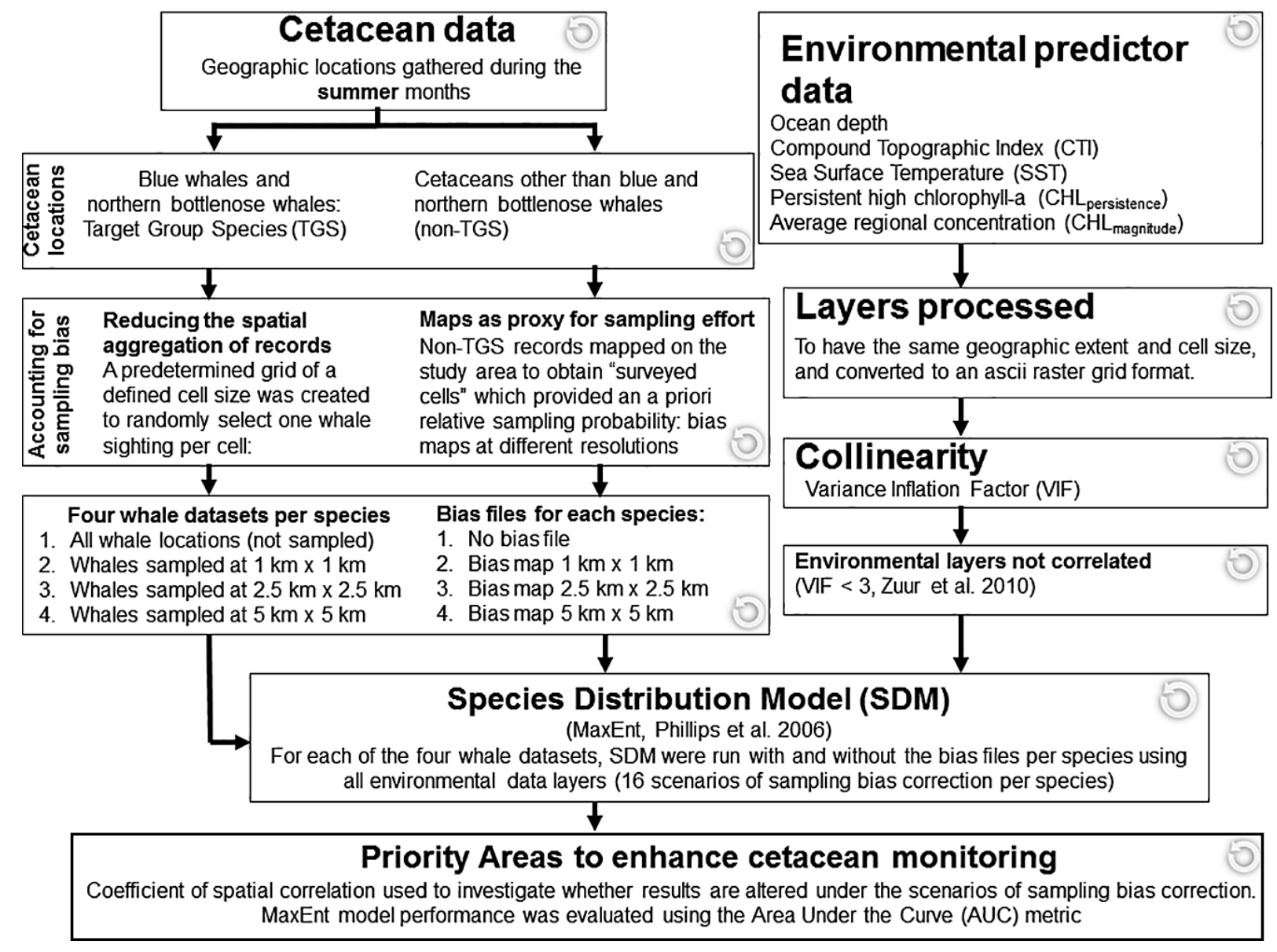

Fig. 4. Approach used to build species distribution models (SDMs) and predict priority areas for blue Balaenoptera musculus and northern bottlenose whales Hyperoodon ampullatus in the Northwest Atlantic Ocean (NWAO). The cetacean and environmental data used are presented in Figs. 1-3; maps derived from SDM results are presented in Fig. 5. Light grey circular arrows indicate that this SDM approach will continue to be used as part of an iterative, adaptive process in the region, including updated data as it becomes available and thus further refining and validating the SDM results to improve our understanding of the distribution of cetaceans in the NWAO 
2012). In this context, we identified and mapped 10 areas that already exist in the NWAO and that may provide some level of protection for blue and northern bottlenose whales (see DFO 2009, 2015). In order to give an example of additional human-caused stressors for these species at risk in the NWAO, we mapped selected activities that are known to contribute a significant amount of noise in the marine environment: shipping and oil and gas exploration. To represent shipping traffic, we obtained and mapped data on commercial shipping from the Canadian Year-Round Shipping Traffic Atlas, which corresponds to the Automatic Identification System (AIS) mean traffic density of all ships in 2013 (Simard et al. 2014). To represent oil and gas exploration, we obtained data on released seismic surveys from the 2 Atlantic Canadian Offshore Petroleum Boards: Canada-Newfoundland and Labrador Offshore Petroleum Board (C-NLOPB) and Canada-Nova Scotia Offshore Petroleum Board (C-NSOPB). Digital data on released seismic operations off Nova Scotia was obtained from the C-NSOPB (http://callforbids.ca/ data-environment/gis-information).

\section{RESULTS}

\section{SDM: priority areas to enhance blue and northern bottlenose whale monitoring efforts}

Preliminary analyses showed that the environmental variables selected in this study were not correlated, and thus we were able to use all variables in the SDM (Table 3). All models had high AUC values (mean >0.81), and the majority of maps derived from the different scenarios of sampling bias correction presented a positive correlation for all species $(r>0.75)$, with the exception of

Table 3. Variance Inflation Factor (VIF) used to investigate collinearity between environmental variables: ocean depth, compound topographic index (CTI), sea surface temperature (SST), and areas of persistently high chl a concentration $\left(\mathrm{CHL}_{\text {pers }}\right)$. Note that the variable 'regional concentrations of chl a' $\left(\mathrm{CHL}_{\text {magn }}\right)$ had only 4 values (one for each region; Fig. 3), and thus was not included in this analysis

\begin{tabular}{|lc|}
\hline Environmental variables & VIF \\
\hline Ocean depth & 1.61 \\
CTI & 1.41 \\
SST summer & 1.44 \\
CHL $_{\text {pers }}$ (summer) & 1.58 \\
CHL $_{\text {pers }}$ (spring) & 1.80 \\
\hline
\end{tabular}

the results for northern bottlenose whales that did not include a bias map ( $\mathrm{r}<0.42$; Table 4, Fig. S2 in the Supplement at www.int-res.com/articles/suppl/ n032p437_supp.pdf). A visual examination of the maps shows that while the overall distribution patterns of priority areas were similar across all scenarios of sampling bias correction (see Figs. S1 \& S2 in the Supplement), there are important differences in some of the areas. For example, for blue whales (without sub-sampling), the Laurentian Channel showed low predicted priority when using a bias file at $5 \mathrm{~km}$, and high predicted priority when using a bias file of 2.5 or $1 \mathrm{~km}$. In general, the maps that did not incorporate a bias file and included the total set of whale sighting records (no sampling) predicted a relatively smaller proportion of high and moderate priority areas compared with models that did utilize the bias files, and the minimum number of whale records (sampling on a $5 \times 5$ km grid; see Figs. S1 \& S2 in the Supplement). We used SDM results that incorporated the bias file to present priority areas to target future monitoring. The bias file we used (see Fig. 5) was generated at $1 \mathrm{~km}$, which we considered to be a reasonable radius at which observers from vessel-based platforms would be able to detect and identify cetaceans (i.e. differentiate between TGS and non-TGS records). However, it is important to note that until model validation is conducted (e.g. dedicated field surveys), all SDM outputs presented in the scenarios of sampling bias correction are reasonable predictions with which to target monitoring efforts.

We calculated the relative contributions of environmental predictor variables to the SDM to evaluate their individual importance for each of the 8 scenarios of sampling bias correction (Table 5). Ocean depth $(>44 \%)$ and $\mathrm{SST}_{\text {summer }}(>22 \%)$ had the greatest contribution to the northern bottlenose whale models. $\mathrm{SST}_{\text {summer }}$ had the greatest contribution to the blue whale models $(>35 \%)$, followed by $\mathrm{CHL}_{\text {magn }}$ during spring $(>21 \%$ ), and ocean depth (12\%) (with the exception of the models in which the bias file was not included; in those cases, ocean depth and $\mathrm{SST}_{\text {summer }}$ had the greatest contribution at $>34 \%$ ). Jacknife output, used as a complementary method for assessing the importance of environmental predictor variables (see Yost et al. 2008, our Table 2), confirmed the importance of ocean depth, $\mathrm{SST}_{\text {summer, }}$ and $\mathrm{CHL}_{\text {magn }}$ during spring in the models (higher training gain and test AUC values). $\mathrm{CHL}_{\text {magn }}$ during summer, $\mathrm{CHL}_{\text {pers }}$ during spring and summer, and CTI contributed relatively little to the models for both species $(<11 \%)$. 
Table 4. Pearson's rank correlation coefficient between each set of MaxEnt model predictions for blue whales Balaenoptera musculus and northern bottlenose whales Hyperoodon ampullatus under each scenario of predicted habitat suitability. The majority of maps derived from the different scenarios of sampling bias correction presented a positive high correlation for all species, with the exception of the results for northern bottlenose whales that did not include a bias map (see shaded values)

\begin{tabular}{|c|c|c|c|c|c|c|c|c|c|c|c|c|c|c|c|c|c|}
\hline \multirow{2}{*}{$\begin{array}{l}\text { Bias } \\
(\mathrm{km})\end{array}$} & \multirow{2}{*}{$\begin{array}{l}\text { Sampling } \\
\quad(\mathrm{km})\end{array}$} & \multicolumn{2}{|c|}{$\longrightarrow$} & \multicolumn{2}{|c|}{1} & \multicolumn{4}{|c|}{-2.5} & \multicolumn{4}{|c|}{-5} & \multicolumn{4}{|c|}{ None- } \\
\hline & & None & 1 & 2.5 & 5 & None & 1 & 2.5 & 5 & None & 1 & 2.5 & 5 & None & 1 & 2.5 & 5 \\
\hline \multicolumn{18}{|c|}{ Blue whales } \\
\hline \multirow[t]{4}{*}{1} & None & - & & & & & & & & & & & & & & & \\
\hline & 1 & 0.77 & - & & & & & & & & & & & & & & \\
\hline & 2.5 & 0.77 & 1.00 & - & & & & & & & & & & & & & \\
\hline & 5 & 0.77 & 1.00 & 1.00 & - & & & & & & & & & & & & \\
\hline \multirow[t]{4}{*}{2.5} & None & 0.83 & 0.97 & 0.97 & 0.97 & - & & & & & & & & & & & \\
\hline & 1 & 0.82 & 0.97 & 0.97 & 0.97 & 1.00 & - & & & & & & & & & & \\
\hline & 2.5 & 0.82 & 0.97 & 0.97 & 0.97 & 1.00 & 1.00 & - & & & & & & & & & \\
\hline & 5 & 0.82 & 0.97 & 0.97 & 0.97 & 1.00 & 1.00 & 1.00 & - & & & & & & & & \\
\hline \multirow[t]{4}{*}{5} & None & 0.87 & 0.95 & 0.95 & 0.95 & 0.98 & 0.98 & 0.98 & 0.98 & - & & & & & & & \\
\hline & 1 & 0.82 & 0.97 & 0.97 & 0.97 & 1.00 & 1.00 & 1.00 & 1.00 & 0.98 & - & & & & & & \\
\hline & 2.5 & 0.82 & 0.97 & 0.97 & 0.97 & 1.00 & 1.00 & 1.00 & 1.00 & 0.98 & 1.00 & - & & & & & \\
\hline & 5 & 0.82 & 0.97 & 0.97 & 0.97 & 1.00 & 1.00 & 1.00 & 1.00 & 0.98 & 1.00 & 1.00 & - & & & & \\
\hline \multirow[t]{4}{*}{ None } & None & 0.98 & 0.76 & 0.76 & 0.76 & 0.82 & 0.82 & 0.82 & 0.82 & 0.87 & 0.82 & 0.82 & 0.82 & - & & & \\
\hline & 1 & 0.98 & 0.78 & 0.78 & 0.78 & 0.84 & 0.83 & 0.83 & 0.83 & 0.88 & 0.83 & 0.83 & 0.83 & 0.99 & - & & \\
\hline & 2.5 & 0.98 & 0.80 & 0.80 & 0.80 & 0.85 & 0.85 & 0.85 & 0.85 & 0.90 & 0.85 & 0.85 & 0.85 & 0.97 & 0.99 & - & \\
\hline & 5 & 0.98 & 0.79 & 0.79 & 0.79 & 0.84 & 0.84 & 0.84 & 0.84 & 0.88 & 0.84 & 0.84 & 0.84 & 0.98 & 0.99 & 0.99 & - \\
\hline \multicolumn{18}{|c|}{ Northern bottlenose whales } \\
\hline \multirow[t]{4}{*}{1} & None & - & & & & & & & & & & & & & & & \\
\hline & 1 & 1.00 & - & & & & & & & & & & & & & & \\
\hline & 2.5 & 0.98 & 0.99 & - & & & & & & & & & & & & & \\
\hline & 5 & 0.95 & 0.95 & 0.97 & - & & & & & & & & & & & & \\
\hline \multirow[t]{4}{*}{2.5} & None & 0.97 & 0.97 & 0.94 & 0.90 & - & & & & & & & & & & & \\
\hline & 1 & 0.97 & 0.97 & 0.95 & 0.91 & 1.00 & - & & & & & & & & & & \\
\hline & 2.5 & 0.97 & 0.98 & 0.96 & 0.94 & 0.99 & 0.99 & - & & & & & & & & & \\
\hline & 5 & 0.95 & 0.94 & 0.95 & 0.97 & 0.93 & 0.94 & 0.97 & - & & & & & & & & \\
\hline \multirow[t]{4}{*}{5} & None & 0.95 & 0.95 & 0.93 & 0.91 & 0.94 & 0.94 & 0.94 & 0.92 & - & & & & & & & \\
\hline & 1 & 0.95 & 0.95 & 0.93 & 0.91 & 0.94 & 0.95 & 0.95 & 0.92 & 1.00 & - & & & & & & \\
\hline & 2.5 & 0.95 & 0.95 & 0.93 & 0.93 & 0.92 & 0.93 & 0.94 & 0.92 & 0.99 & 0.99 & - & & & & & \\
\hline & 5 & 0.93 & 0.93 & 0.92 & 0.94 & 0.89 & 0.89 & 0.92 & 0.94 & 0.96 & 0.97 & 0.98 & - & & & & \\
\hline \multirow[t]{4}{*}{ None } & None & 0.35 & 0.34 & 0.35 & 0.31 & 0.38 & 0.38 & 0.38 & 0.36 & 0.42 & 0.41 & 0.41 & 0.36 & - & & & \\
\hline & 1 & 0.34 & 0.34 & 0.34 & 0.31 & 0.37 & 0.37 & 0.38 & 0.36 & 0.42 & 0.41 & 0.41 & 0.36 & 0.99 & - & & \\
\hline & 2.5 & 0.34 & 0.34 & 0.34 & 0.32 & 0.37 & 0.37 & 0.38 & 0.36 & 0.41 & 0.40 & 0.40 & 0.36 & 0.99 & 0.99 & - & \\
\hline & 5 & 0.35 & 0.35 & 0.35 & 0.33 & 0.38 & 0.38 & 0.39 & 0.38 & 0.43 & 0.42 & 0.42 & 0.38 & 0.99 & 0.99 & 0.99 & - \\
\hline
\end{tabular}

In general, areas of high and moderate priority for blue and bottlenose whales were in deep-water regions along the continental slope of the NWAO (Fig. 5). For northern bottlenose whales, priority areas for monitoring were concentrated on the offshore margins of the eastern Scotian Shelf, and the Newfoundland and Labrador Shelves, including several submarine canyons, deep water areas, and basins. In addition, priority areas for northern bottlenose whales were also indicated in near-shore areas off the northern tip of Labrador. In the case of blue whales, the majority of priority areas were along the slopes of the eastern and western Scotian Shelf and south of the Newfoundland Shelf. Areas of low priority were highlighted in a small region around north- ern Labrador. Deep water regions beyond the shelf break, which coincide with areas of limited or nonexistent survey effort (Fig. 1), exhibited very low priority for targeting blue whale monitoring efforts (Fig. 5).

\section{Conservation areas, shipping, and seismic surveys in the NWAO}

We mapped 10 areas in the NWAO which currently may provide some level of protection for blue and northern bottlenose whales (see DFO 2009, 2015). These areas include 1 MPA (The Gully), proposed MPAs (or Areas of Interest, AOI), areas identified as 
Table 5. Average test area under the curve (AUC) for the replicate runs, AUC standard deviation and analysis of the relative contributions of the environmental variables to the MaxEnt model for blue whales Balaenoptera musculus and northern bottlenose whales Hyperoodon ampullatus under each scenario of predicted habitat suitability. The greatest relative contributions for each model are indicated in bold (largest contribution) and italics (second and third largest contributions). SST: sea surface temperature; $\mathrm{CHL}_{\text {magn }}$ : average of the median chl a concentration; $\mathrm{CHL}_{\text {pers }}$ : relative contribution of persistently high chl $a$; CTI: compound topographic index

\begin{tabular}{|c|c|c|c|c|c|c|c|c|c|c|}
\hline $\begin{array}{l}\text { Bias } \\
(\mathrm{km})\end{array}$ & $\begin{array}{l}\text { Sampling } \\
(\mathrm{km})\end{array}$ & AUC & $\begin{array}{c}\text { AUC } \\
\text { (SD) }\end{array}$ & $\begin{array}{l}\text { Ocean } \\
\text { depth }\end{array}$ & $\begin{array}{c}\text { SST } \\
\text { Summer }\end{array}$ & $\begin{array}{c}\mathrm{CHL}_{\text {magn }} \\
\text { spring }\end{array}$ & $\begin{array}{l}\mathrm{CHL}_{\text {magn }} \\
\text { summer }\end{array}$ & $\begin{array}{l}\mathrm{CHL}_{\text {pers }} \\
\text { spring }\end{array}$ & $\begin{array}{l}\mathrm{CHL}_{\text {pers }} \\
\text { summer }\end{array}$ & CTI \\
\hline \multicolumn{11}{|c|}{ Blue whales } \\
\hline \multirow[t]{4}{*}{1} & None & 0.84 & 0.165 & 17.9 & 37.5 & 26.0 & 8.6 & 5.9 & 2.6 & 1.5 \\
\hline & 1 & 0.84 & 0.200 & 18.3 & 37.2 & 25.5 & 8.7 & 6.2 & 2.5 & 1.6 \\
\hline & 2.5 & 0.84 & 0.337 & 17.4 & 37.7 & 22.7 & 10.6 & 7.1 & 2.4 & 2.1 \\
\hline & 5 & 0.81 & 0.521 & 12.9 & 39.1 & 22.6 & 12.2 & 8.1 & 3.0 & 2.1 \\
\hline \multirow[t]{4}{*}{2.5} & None & 0.84 & 0.165 & 20.5 & 37.6 & 24.0 & 7.3 & 5.9 & 2.7 & 2.0 \\
\hline & 1 & 0.85 & 0.192 & 19.1 & 36.8 & 25.4 & 8.1 & 5.9 & 2.6 & 2.1 \\
\hline & 2.5 & 0.83 & 0.338 & 20.3 & 37.5 & 25.5 & 6.3 & 6.4 & 2.1 & 1.9 \\
\hline & 5 & 0.81 & 0.526 & 15.5 & 39.9 & 23.4 & 9.9 & 7.3 & 2.5 & 1.5 \\
\hline \multirow[t]{4}{*}{5} & None & 0.85 & 0.163 & 21.3 & 42.6 & 21.0 & 5.2 & 4.6 & 3.2 & 2.1 \\
\hline & 1 & 0.84 & 0.205 & 21.1 & 41.7 & 24.0 & 4.1 & 3.9 & 3.3 & 2.0 \\
\hline & 2.5 & 0.84 & 0.337 & 21.6 & 42.8 & 21.2 & 5.4 & 4.2 & 2.8 & 1.9 \\
\hline & 5 & 0.83 & 0.525 & 17.7 & 45.7 & 22.6 & 4.0 & 5.2 & 2.4 & 2.4 \\
\hline \multirow[t]{4}{*}{ None } & None & 0.96 & 0.036 & 44.4 & 36.7 & 2.4 & 2.9 & 1.4 & 11.5 & 0.6 \\
\hline & 1 & 0.96 & 0.038 & 44.1 & 34.8 & 1.7 & 2.0 & 2.9 & 13.9 & 0.6 \\
\hline & 2.5 & 0.96 & 0.037 & 43.9 & 35.8 & 1.8 & 2.3 & 3.6 & 12.2 & 0.5 \\
\hline & 5 & 0.96 & 0.035 & 44.1 & 36.0 & 3.3 & 2.1 & 3.6 & 10.4 & 0.5 \\
\hline \multicolumn{11}{|c|}{ Northern bottlenose whales } \\
\hline \multirow[t]{4}{*}{1} & None & 0.89 & 0.044 & 64.8 & 27.6 & 0.7 & 1.6 & 2.1 & 1.5 & 1.7 \\
\hline & 1 & 0.89 & 0.042 & 64.8 & 27.7 & 0.4 & 1.6 & 2.0 & 1.6 & 2.0 \\
\hline & 2.5 & 0.88 & 0.048 & 65.7 & 25.4 & 0.6 & 2.2 & 1.6 & 2.1 & 2.5 \\
\hline & 5 & 0.87 & 0.049 & 64.8 & 25.7 & 0.5 & 3.0 & 1.0 & 3.1 & 1.9 \\
\hline \multirow[t]{4}{*}{2.5} & None & 0.88 & 0.057 & 56.4 & 32.9 & 2.1 & 1.6 & 3.9 & 2.1 & 1.0 \\
\hline & 1 & 0.88 & 0.055 & 55.4 & 32.8 & 2.4 & 1.7 & 3.9 & 2.0 & 1.8 \\
\hline & 2.5 & 0.87 & 0.063 & 59.8 & 32.2 & 0.2 & 1.8 & 2.6 & 1.8 & 1.6 \\
\hline & 5 & 0.85 & 0.063 & 61.7 & 31.3 & 0.1 & 1.1 & 1.7 & 1.5 & 2.6 \\
\hline \multirow[t]{4}{*}{5} & None & 0.88 & 0.056 & 52.0 & 36.4 & 0.4 & 1.5 & 3.0 & 3.8 & 3.0 \\
\hline & 1 & 0.88 & 0.057 & 51.8 & 35.9 & 0.4 & 1.7 & 3.0 & 3.7 & 3.5 \\
\hline & 2.5 & 0.87 & 0.062 & 53.6 & 36.4 & 0.4 & 1.6 & 2.2 & 2.3 & 3.4 \\
\hline & 5 & 0.84 & 0.072 & 54.9 & 36.3 & 0.4 & 1.6 & 1.8 & 1.8 & 3.1 \\
\hline \multirow[t]{4}{*}{ None } & None & 0.93 & 0.036 & 60.0 & 26.0 & 0.8 & 1.0 & 0.4 & 7.5 & 4.2 \\
\hline & 1 & 0.93 & 0.038 & 59.9 & 26.0 & 0.9 & 1.1 & 0.2 & 7.3 & 4.6 \\
\hline & 2.5 & 0.92 & 0.042 & 62.1 & 28.2 & 1.1 & 0.8 & 0.4 & 2.3 & 5.1 \\
\hline & 5 & 0.91 & 0.044 & 67.4 & 22.6 & 1.3 & 1.5 & 0.6 & 1.4 & 5.2 \\
\hline
\end{tabular}

critical habitat for cetaceans, and fishery closure areas. In this study, we refer to these as 'conservation areas'. Note that the designation of these areas was primarily for purposes other than the protection of blue or northern bottlenose whales (e.g. North Atlantic right whale protection). We produced 2 maps that included the conservation areas as well as the SDM results for each species (Fig. 6). We also mapped selected activities that are known to contribute a significant amount of noise in the marine environment: shipping routes and oil and gas exploration (Fig. 7). We were unable to obtain digital data from New- foundland and Labrador, and instead obtained information from a report by C-NLOPB (2010). Contrary to the shipping data, which is representative of a single year (2013), information on seismic activity is the compilation of all surveys that were released prior to 2010. Consequently, while shipping data may represent current overall distribution of this activity in a given year, the information on the distribution of seismic effort can vary greatly each year (i.e. seismic surveys may occur once in a particular area but may not be repeated; or surveys may occur multiple times in the same area for several years). 

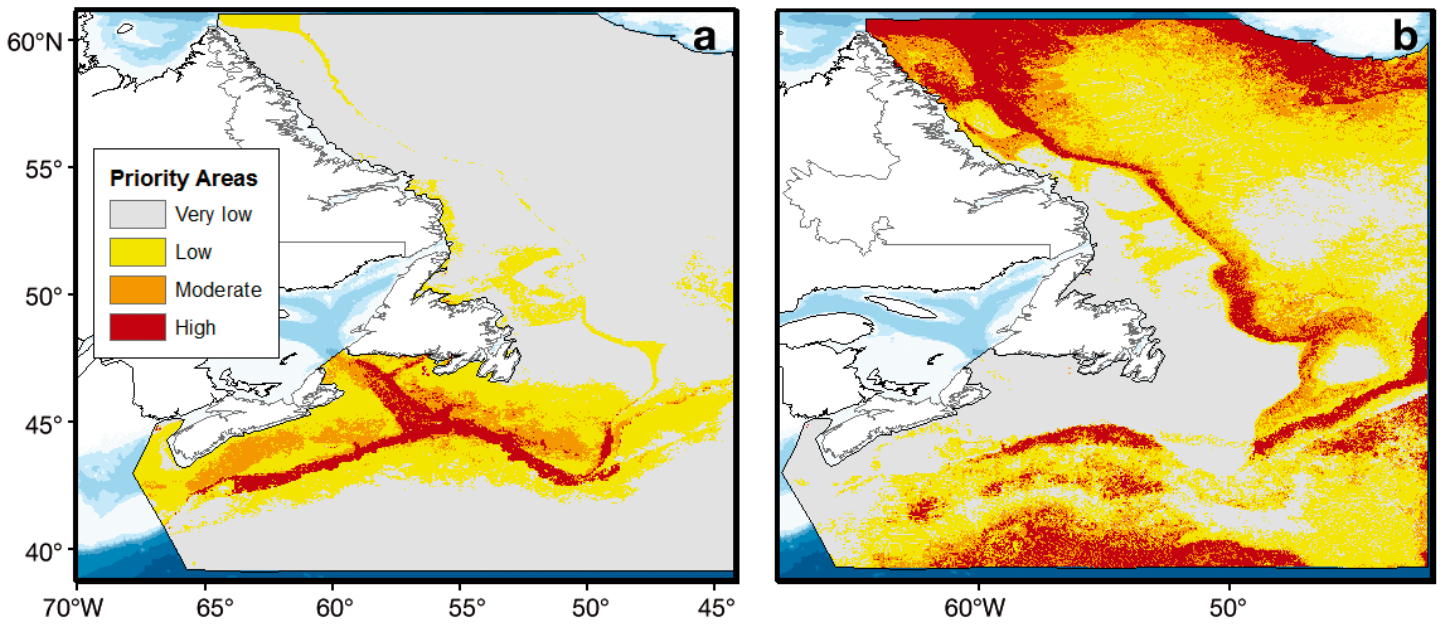

Fig. 5. Averaged MaxEnt models for (a) blue whales Balaenoptera musculus and (b) northern bottlenose whales Hyperoodon ampullatus for summer (June to August). The models used the geographic locations of whales in Fig. 1 sub-sampled on a $5 \times 5$ $\mathrm{km}$ grid $\left(\mathrm{N}_{\text {northern bottlenose whales }}=277 ; \mathrm{N}_{\text {blue whales }}=150\right)$, bias maps of non-TGS records $(1 \mathrm{~km})$, and the following predictor environmental variables: ocean depth, compound topographic index (CTI), sea surface temperature (SST) in the summer, areas ofpersistently high chl a concentration in the spring and summer, and regional chl a magnitude in the spring and summer. $\mathrm{AUC}_{\text {northern bottlenose whales }}=0.87( \pm 0.049) ; \mathrm{AUC}_{\text {blue whales }}=0.81( \pm 0.0521)$. Highly and moderately suitable habitat (red and orange colours) are interpreted as areas of higher priority to target and enhance for further monitoring efforts for these species
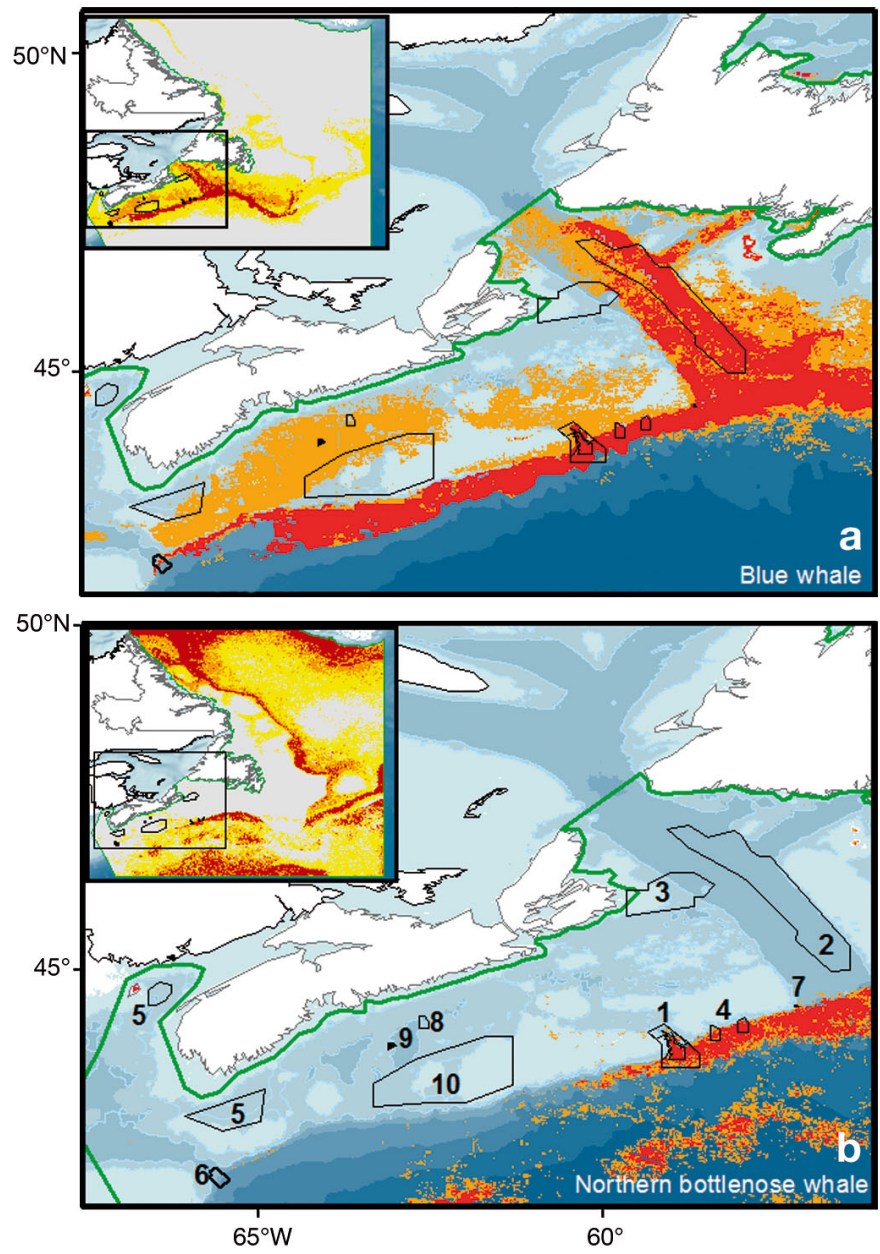

Fig. 6. Conservation areas currently designated (or in the process of being designated) that may provide some degree of protection for (a) blue whales Balaenoptera musculus and (b) northern bottlenose whales Hyperoodon ampullatus in our study area (green line). Note that there was no representation of conservation areas in the northern part of our study area. Conservation areas are numbered in (b) as: 1: Gully Marine Protected Area (which includes northern bottlenose whale critical habitat inside its boundaries); 2: Laurentian Channel Area Of Interest (AOI); 3: St. Ann's Bank AOI; designated critical habitat for 4: northern bottlenose whales and 5: North Atlantic right whale; 6: Northeast Channel Coral Conservation Area; 7: Lophelia Coral Conservation Area (The Stone Fence); 8: Emerald Basin Sponge Conservation Area; 9: Sambro Bank Sponge Conservation Area; and 10: the Haddock box. This map includes areas of high priority for further monitoring efforts for blue and northern bottlenose whales (high suitability in red; moderate suitability in orange as per Fig. 5)

\section{DISCUSSION}

\section{MaxEnt results: indicators of priority areas for increased cetacean monitoring}

With AUC values indicating good model performance (>0.81 for all model runs; Table 5), our SDM predicted high and moderate priority areas for blue and northern bottlenose whale monitoring efforts in the NWAO during summer. Importantly, we do not interpret the results of our SDM as the most accurate distribution of blue and northern bottlenose whales 

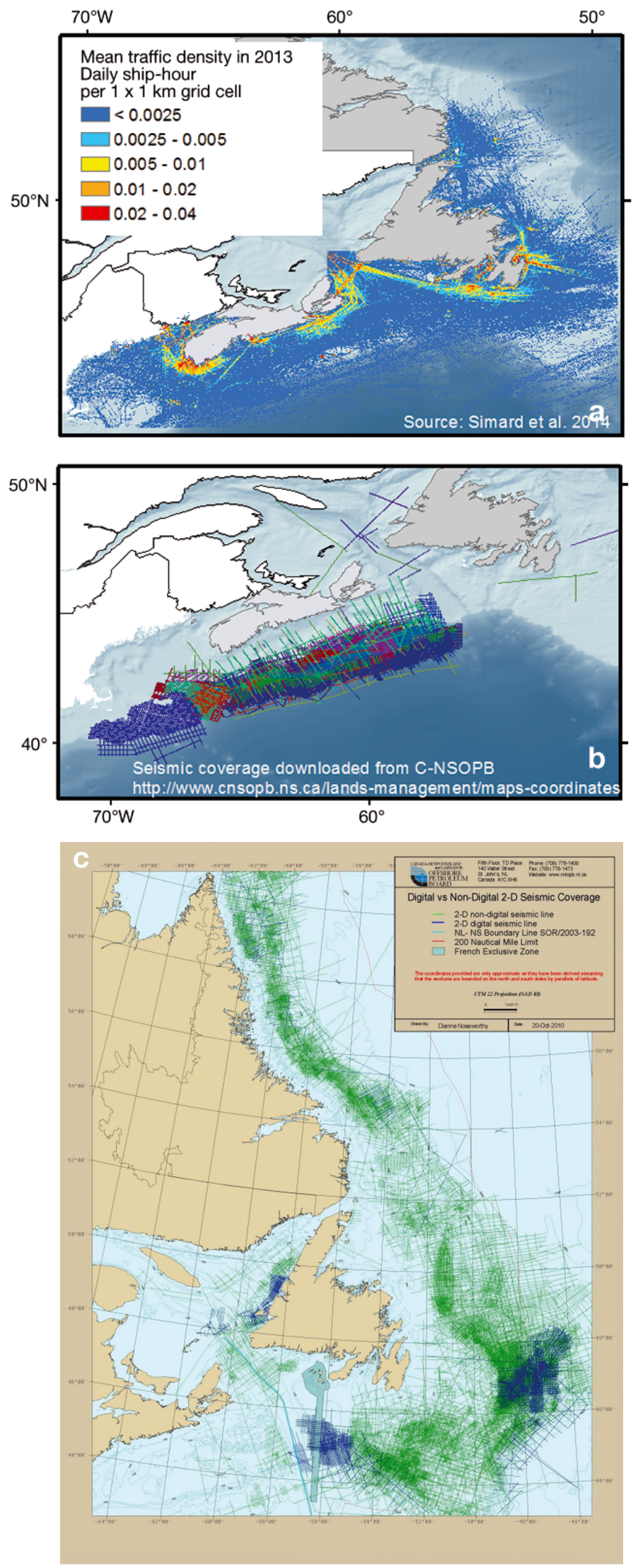

Released 2-D seismic coverage from 1964 to 2010 in the NWAO because this is beyond the scope of our model's evaluation capabilities. Although AUC provides an adequate evaluation of model performance (see Phillips et al. 2006), caution is warranted because it is not a perfect measure of model accuracy, in part due to a lack of true species-absence data (Lobo et al. 2008, Fourcade et al. 2014). There are currently no alternatives to evaluate model performance for this type of presence-only approach (Merow et al. 2013). Consequently, SDMs in this study were important tools with which to highlight priority areas that warrant increased attention and monitoring efforts for blue and northern bottlenose whales. Our analyses also demonstrated important differences in some of the predicted priority areas depending on the scenarios of sampling bias corrections (e.g. Laurentian Channel for blue whales). We therefore recommend that all SDM outputs presented in a scenario of sampling bias correction should be considered as plausible predictions, at least until more dedicated survey efforts and model validation become available.

\section{Priority areas for increased monitoring of blue whales}

$\mathrm{SST}, \mathrm{CHL}_{\text {magn }}$ during spring, and ocean depth provided the greatest contribution to the blue whale SDM. SST maps highlight areas related to increased biological productivity and aggregated prey, in particular at persistent thermal fronts where higher food densities are found, leading to predictable feeding locations for many marine species (Podesta et al. 1993, Etnoyer et al. 2006, Doniol-Valcroze et al. 2007). Such areas occurring in our study area include regions where warm waters from the Gulf Stream meet the cold waters from the Labrador Current (Fig. 2c).

Lagged regional values of chl a concentration (i.e. $\mathrm{CHL}_{\text {magn }}$ during spring), which provided relatively high contributions to the blue whale models, represent an index of regional concentrations of phyto-

Fig. 7. (a) Commercial shipping from the Canadian YearRound Shipping Traffic Atlas reflecting the mean traffic density of all ships in 2013 tracked via the Automatic Identification System (Simard et al. 2014). Released seismic coverage data from offshore Nova Scotia (Source: Canada-Nova Scotia Offshore Petroleum Board, C-NSOPB). (c) Released 2-D seismic data coverage offshore Newfoundland and Labrador (digitally recorded in blue and non-digital in green) (Source: Canada Newfoundland and Labrador Off-shore Petroleum Board C-NLOPB 2010) 
plankton biomass. Phytoplankton, through its fixation of inorganic carbon into organic compounds using photosynthesis, provides food for euphausiids, which are key prey for blue whales. Lagged chlorophyll values likely account for the time lag needed for primary producers to transfer to secondary producers (Schoenherr 1991, Kenney et al. 1996, Fiedler et al. 1998, Simard \& Lavoie 1999). Areas with relatively high primary production have been used in other SDM studies to locate biological hotspots (Palacios et al. 2006, Kobayashi et al. 2011) and to predict cetacean distribution (Forney et al. 2015, Mannocci et al. 2015). It is important to note that most blue whale records (Fig. 1) are present in the neritic south region, which has the highest values of $\mathrm{CHL}_{\text {magn }}$ in the study area (Fig. 3). Consequently, the regional values of chl a concentration in our study are related to primary production but also to the distinctiveness of geographic regions shown in Fig. 3d, which are characterized by unique marine communities and food web systems (Devred et al. 2007, 2009, Longhurst 2007). Cetacean records were not part of the marine species used to characterize these unique regions shown in Fig. $3 d_{\text {; }}$ however, the relatively high contribution of lagged regional $\mathrm{CHL}_{\text {magn }}$ suggests that this partitioning is likely important to understand blue whales' spatial distribution, at least during the summer.

Ocean depth provided the third largest contribution to the blue whale SDM. This result is consistent with the findings of a previous SDM study (Abgrall 2009), and highlights the relative importance of ocean depth in predicting the distribution of blue whales in waters off Newfoundland, particularly areas characterized by deep water and steeper seabed slopes (Abgrall 2009).

Priority areas for blue whales were primarily located along the outer margins of the eastern and western Scotian Shelf and southern portion of the Newfoundland Shelf (Figs. 5 \& 6). There are several submarine canyons there in which baleen whales are known to feed as they are areas of enhanced shelfbreak upwelling (for a review, see Moors-Murphy 2014). Due to the known enhanced productivity of shelf edges, frontal zones, and upwelling, these areas are also important for other marine groups such as seabirds (Weimerskirch 2007). Similarly, the shelf edge area south of Newfoundland is also a key area characterized by along-slope currents that concentrate marine fish eggs, larvae, and juveniles from other regions of the NWAO (Han \& Kulka 2009). According to our SDM results, this area is also important for northern bottlenose whales. Given the current lack of monitoring effort and lack of historical data from the southern edge of the Newfoundland Shelf, this area appears to be an essential target for future monitoring efforts - and possibly protection — for northern bottlenose and blue whales, and potentially other marine species. Areas of low priority for blue whales were highlighted in the region north of Labrador and in the waters off eastern Newfoundland. Further validation of this model prediction is necessary, as it is not clear whether the low predictions are due to a paucity of data or whether these areas may also offer important habitat for blue whales, since blue whale vocalizations have been recorded offshore in the northern region (Clark 1995).

The blue whale is a migratory species that is known to frequent the Gulf of St. Lawrence during the summer and the eastern Scotian Shelf between January and November (Hooker et al. 1999, Reeves 2000 and references therein, Sears et al. 1990). Persistently high chl a (as a proxy for prey availability) has been observed year-round in many areas of the Scotian Shelf (Fuentes-Yaco et al. 2015). Blue whales vocalize on the Scotian Shelf throughout the year (Marotte \& Moors-Murphy 2015), and satellite-tagged individuals are present during the spring and winter months (V. Lesaqe pers. comm.). This study only considered blue whale sightings during the summer, and thus further studies should include a seasonal component to further refine and validate areas of high priority, and potentially high suitability, for this species.

\section{Priority areas for increased monitoring of northern bottlenose whales}

Ocean depth provided the greatest contribution to the northern bottlenose whale SDM, followed by average SST during the summer. SST is an important predictor of diversity and abundance of marine life in other ecosystems (Worm et al. 2003, Morato et al. 2010, Pirotta et al. 2011), including diversity of deepwater cetaceans in the northwest Atlantic and eastern Pacific Oceans (Whitehead et al. 2010). It is not surprising that ocean depth was important in explaining the distribution of whales that feed primarily on deepwater squid Gonatus spp., as this has been observed in other studies (Reeves et al. 1993 and references therein, Gowans \& Whitehead 1995, MacLeod et al. 2003, Whitehead et al. 2003). Deep water and steep seabed topography were often identified as the most important variables explaining the presence of deepdiving whales (see review by Moors-Murphy 2014).

High and moderate priority areas for northern bottlenose whales were situated along the outer margins 
of the Scotian Shelf and the Newfoundland and Labrador Shelves, including several submarine canyons and deep basins (Fig. 5). The eastern Scotian Shelf and the shelf break off Newfoundland and Labrador were identified as relatively high priority. These 2 areas are the respective primary ranges for the well-studied Scotian Shelf northern bottlenose population (year-round residents of the Gully, Shortland, and Haldimand submarine canyons; Hooker et al. 1999, Wimmer \& Whitehead 2004, DFO 2009, Moors 2012), and the Davis Strait-Baffin BayLabrador Sea population, which is distributed further north (Dalebout et al. 2001, 2006).

Northern bottlenose whales are deep divers that are known to prefer deep-water habitat (Compton 2004); however, some of the high priority areas predicted by the SDM included areas away from great depths, such as the shallower and coastal regions around the northern tip of Labrador (Fig. 5). There are occasional reports of northern bottlenose whales in very shallow waters in Newfoundland and Labrador where the whales appear to be pursuing aggregations of near-shore prey (J. Lawson pers. obs.), and reports by response networks of animals stranded or distressed in coastal waters (T. Wimmer, pers. obs.). This is another example of the lack of dedicated effort to identify true absences in the NWAO given that, in order to detect rare species such as beaked whales, multiple visual or acoustic surveys of the same areas are often needed (Kaschner et al. 2006). Thus, further efforts should aim to investigate the suitability and actual use of these areas for this species.

Offshore areas along the Flemish cap and along the shelf break south of Newfoundland were also indicated as high priority areas for northern bottlenose whales, although these areas had significantly lower sampling effort compared with the Gully MPA and northern Labrador. The boundary between the Scotian Shelf population and the Davis Strait-Baffin BayLabrador Sea population has been arbitrarily drawn near the Flemish Pass (more specifically, following the boundary separating Division 3L from Divisions $3 \mathrm{~N}$ and $3 \mathrm{O}$ used by NAFO; COSEWIC 2011, their Fig. 4). It is unknown whether the individuals sighted in the boundary region belong to the Scotian Shelf or to the Davis Strait-Baffin Bay-Labrador Sea population, and it is unknown whether these populations are linked (COSEWIC 2011). The SDM results highlight that, theoretically, there is no clear division between these regions in terms of habitat that might be suitable for both populations. In addition, results show that the area along the Flemish cap and the shelf break off southern and eastern Newfoundland warrants improved monitoring efforts to find and better characterize northern bottlenose whale habitat.

Although the SDM analyses were limited to summer (when the majority of cetacean sightings were collected), the priority areas identified for northern bottlenose whales likely represents their year-round distribution, at least in the eastern Scotian Shelf where these whales are known to be resident (i.e. Haldimand, Shortland, and Gully canyons).

\section{Do priority areas for whales at risk overlap with areas that provide protection in the NWAO?}

There is minimal overlap between current conservation areas and regions we identified as being of high or moderate priority for blue and northern bottlenose whales (Fig. 6). Areas predicted to be of high or moderate priority for blue and northern bottlenose whales do overlap with the Gully MPA and the designated critical habitat for northern bottlenose whales (Areas 1 and 4 in Fig. 6). These 3 submarine canyons, however, correspond to less than $1 \%$ of the entire study area, and human activities are largely restricted in only one of them (e.g. no commercial fishing of any type is permitted in Zone 1 of the Gully MPA).

Areas of moderate priority for blue and northern bottlenose whales partially overlap fishing closure zones in the Scotian Shelf, and areas of moderate priority for blue whales overlap with the zones designated as critical habitat for North Atlantic right whales in the Bay of Fundy (Area 5 in Fig. 6). Although these zones were not specifically designated for the protection of blue and northern bottlenose whales, our modelling results suggest that management measures created for other marine organisms may have indirect benefits for these species. Specifically, less fishing gear in the water potentially benefits whales by reducing entanglement risk (Vanderlaan et al. 2011, Benjamins et al. 2012). Voluntary vessel traffic measures implemented to reduce the number of ship strikes in right whale critical habitat in the Bay of Fundy (Vanderlaan \& Taggart 2009) may also reduce strikes of blue whales in the same area; however, whales outside of this small area of overlap (where high and moderate priority areas were predicted) do not benefit from these measures.

With the exception of a proposed MPA (the Laurentian Channel AOI) in Newfoundland waters (Area 2 in Fig. 6), areas expected to provide some level of protection to cetaceans are located solely in the Scotia Shelf region. The boundaries of the Laurentian 
Channel AOI encompass an area predicted to be of high priority for blue whale monitoring efforts and lower priority for northern bottlenose whale efforts. Overall, there is an urgent need for better understanding, and subsequent protection, of additional blue and northern bottlenose whale habitat off Newfoundland and Labrador.

In summary, there are few practical measures in place in the Canadian NWAO to specifically protect blue and northern bottlenose whale priority areas from human threats (e.g. entanglements in fishing gear, underwater noise). Importantly, in Fig. 6 we are not suggesting that Canada's existing conservation areas are failing to protect blue and bottlenose whales. Instead, we are highlighting that we cannot count on these conservation areas exclusively to protect these whales at risk because those areas were designated to meet other objectives. In the meantime, the conservation areas may be providing some benefit for at least a fraction of the predicted priority areas for blue and northern bottlenose whales.

\section{Shipping and seismic surveys: noise-generating activities that overlap with priority areas for blue and northern bottlenose whales}

We examined examples of human-caused acoustic stressors for these species at risk by mapping shipping routes and oil and gas exploration operations (Fig. 7). Available data on commercial shipping showed considerable traffic in areas close to the coasts of Newfoundland and Nova Scotia (Simard et al. 2014). Shipping activities are poorly documented along the coast of Labrador and in offshore areas, so this finding likely represents an underestimation of traffic in the NWAO. Seismic survey coverage over a period of $40 \mathrm{yr}$ (from the 1960s to 2010) is distributed widely over shelf and shelf edge areas. Due to industry confidentiality standards, seismic survey work is usually not released for 5 to10 yr after field work is completed (e.g. recent data on over $600000 \mathrm{~km}$ of seismic surveys has not yet been publicly released in Newfoundland and Labrador; C-NLOPB 2010).

Areas of high or moderate priority for blue and northern bottlenose whales overlap considerably with these sources of noise (see Figs. 5 \& 7). For instance, high and moderate priority areas for northern bottlenose whales were identified southeast of Newfoundland, a region which is subject to intense oil exploration. Areas of moderate priority were also found in the Grand Banks of Newfoundland where oil exploration and production continues. Areas of high and moderate priority for northern bottlenose whales were also evident off Labrador where oil exploration continues, and production is being planned.

The overlap of cetacean high priority habitat with shipping and seismic activities is of great concern due to the negative effects that these noise-generating human activities can have on marine species, including mammals, fish, and invertebrates (e.g. Thompson et al. 2013, Pirotta et al. 2014, Williams et al. 2015, Robertson et al. 2016 and references therein). Blue whales, for example, are known to alter their vocalizations in the presence of noise generated from seismic airguns (Di Iorio \& Clark 2010) and in the presence of ships (McKenna 2011). Beaked whales are also known to alter their vocalizations and stop foraging in the presence of vessels (Aguilar Soto et al. 2006). Changes in vocalization patterns carry energetic costs, and there are physiological limits to an individual's ability to cope with them (Holt et al. 2015). Remaining in an area of high noise exposure can impact foraging performance or reproductive rates of marine mammals via social disruption, leading to potential long-term consequences for energy budgets or fitness (Richardson et al. 1995, Williams et al. 2006, Lusseau et al. 2009, Pirotta et al. 2014, Tougaard et al. 2015). Hence, in addition to visual surveys, areas of high priority identified in this study should also be prioritized for acoustic monitoring and research on the effects of noise on blue and northern bottlenose whale foraging behaviour. The use of acoustic recorders in areas of high and moderate priority identified in this study will not only provide information on the presence of these species, but may also aid in the investigation of potential effects of noise exposure on whale populations (as in Di Iorio \& Clark 2010, Melcón et al. 2012, Thompson et al. 2013). This information could provide additional support for considering 'lack of acoustic disturbance' as one of the key features of critical habitat and MPAs for endangered whales (DFO 2009, 2011, Williams et al. 2015).

\section{CONCLUSIONS AND RECOMMENDATIONS}

Capitalizing on available long-term data from government, academic, and industry sources, this project used SDM to predict priority areas in which to enhance monitoring efforts for blue and northern bottlenose whales in the NWAO. Results of this work demonstrate that there are currently few conservation areas in the NWAO that protect whales at risk, and that predicted areas of high and moderate priority overlap with areas in which noise-producing ac- 
tivities (shipping and seismic exploration) have been and are occurring. Overlap with activities that generate noise and other activities identified as important threats to these species is concerning, as the sizes of the blue and northern bottlenose whale populations in the NWAO are small and information on their ecology is limited to a small fraction of their distribution. It is important to further evaluate this overlap once results of SDM validations become available, using additional and up-to-date data on human activities to continue the process of assessing which stressors may be preventing the recovery of these species (Vanderlaan et al. 2011, Bombosch et al. 2014).

By highlighting priority areas for species of high conservation importance, this study is a timely component in the process of identifying and delineating potential conservation areas in the NWAO (Government of Canada 2011, King et al. 2013, Westhead et al. 2013). Although the designation of protected areas is an important first step, it is not always an effective way to protect highly mobile species (Mora \& Sale 2011), particularly since noise and fishing gear can cross the boundaries of designated conservation areas. In the long term, we recommend additional conservation measures for blue and northern bottlenose whales, such as the coordination and temporal planning of seismic operations to minimize noise effects (Nowacek et al. 2013, 2015), and potentially, time-area closures to reduce the risk of entanglement in fishing gear (e.g. NMFS 2005). These planning approaches require habitat use information, such as that generated in this study, as well as collaboration between stakeholders including industry, government, and non-governmental sectors (Wright 2014, Wright \& Kyhn 2015).

Our SDM results indicate priority areas to enhance blue and northern bottlenose whale monitoring. Caution is warranted with respect to interpretation of these SDM results, as the majority of cetacean sightings occur in the neritic south and neritic north subregions, and there is a lack of survey effort in large portions of the NWAO, particularly in deep water beyond the shelf break (see Fig. 1). Furthermore, many cetacean sightings are collected through platforms of opportunity rather than systematically. For these reasons, the SDM results presented here represent interim maps pending new information and model validation. We therefore recommend testing the results of this study with new, updated data as it becomes available (see iteration of steps in Fig. 4). As a way forward to improve and validate the SDM, efforts could focus on using cetacean sightings derived from systematic surveys where zeros are available (Law- son \& Gosselin 2009) as well as investigating the possibility of reconstructing the effort associated with some of the platforms of opportunity. Using a small subset of cetacean records from dedicated surveys that may have reliable presence-absence data (e.g. Lawson \& Gosselin 2009) will allow comparisons with the predictions of this work, albeit at a smaller scale (Golding \& Purse 2016, Roberts et al. 2016). We did not have survey effort or zeros for all datasets, so we were unable to generate such analysis here.

SDM can also be improved by incorporating additional dynamic environmental data for an extended period of time (e.g. earlier data on chl $a$ and SST available from other sensors), prey information (e.g. zooplankton), and other relevant predictor layers (e.g. Harris et al. 2014). We also recommend using yearround acoustic detection data to further refine SDM results by including a seasonal component (Clark 1995, Palialexis et al. 2011). These recommendations, and the approach proposed in Fig. 4, can direct additional SDM efforts to other marine species of concern in the NWAO. This will aid in the process of consolidating and increasing information on the distribution and seasonal occurrence of species at risk and human activities in waters off Nova Scotia and Newfoundland and Labrador as an important step towards improving the monitoring, management, and mitigation of human activities in eastern Canadian waters.

Acknowledgements. C.G. was supported by a Natural Sciences and Engineering Research Council post-doctoral Visiting Fellowship funded by the Strategic Program for Ecosystem-Based Research and Advice (SPERA) at the Department of Fisheries and Oceans Canada. We thank Paul Regular for helping in the analysis of data. We thank Yvan Simard and Nathalie Roy for providing data and advice on ship traffic density. We also thank the following institutions for providing sightings of cetaceans: Fisheries and Oceans Canada Maritimes and Newfoundland and Labrador regions, the Canadian Wildlife Service of Environment and Climate Change Canada, the North Atlantic Right Whale Consortium, the University of Rhode Island's Bureau of Land Management for air and opportunistic sightings from the Cetacean and Turtle Assessment Program (CETAP), Lamont-Doheorty Earth Observatory, LGL Ltd. Environmental Research Associates, the National Science Foundation marine seismic surveys, sightings from R/V 'Song of the Whale' 1993 to 2013 (International Fund for Animal Welfare c/o MCR International (http://seamap.env. duke.edu/dataset/1158), and the NOAA Northeast Fisheries Science Center (NEFSC) for sightings from the Aerial Survey - Summer 1998 and the Right Whale Aerial Survey. We thank World Wildlife Fund Canada for supporting the preparation of the cetacean sightings data in DFO Newfoundland and Labrador region. We thank the Remote Sensing Unit at the Bedford Institute of Oceanography, and NASA/Ocean Biology Processing Group for providing the satellite images and facilities for the data processing. We 
thank Marty King, Derek Fenton, Derek Tittensor, and Gary Stenson for support, suggestions and ideas. We also thank the anonymous reviewers for their comments and suggestions to improve the quality of the manuscript.

\section{LITERATURE CITED}

Abgrall P (2009) Defining critical habitat for large whales in Newfoundland and Labrador waters: design and assessment of a step-by-step protocol. PhD thesis, Memorial University of Newfoundland, St. John's

Aguilar Soto N, Johnson M, Madsen PT, Tyack PL, Bocconcelli A, Fabrizio Borsani J (2006) Does intense ship noise disrupt foraging in deep-diving Cuvier's beaked whales (Ziphius cavirostris)? Mar Mamm Sci 22:690-699

Ainley D, Jongsomjit D, Ballard G, Thiele D, Fraser W, Tynan C (2012) Modeling the relationship of Antarctic minke whales to major ocean boundaries. Polar Biol 35: 281-290

Ananjeva NB, Golynsky EE, Li SM, Orlov NL, Tseng HY (2015) Modeling habitat suitability to predict the potential distribution of the Kelung cat snake Boiga kraepelini Steineger, 1902. Russ J Herpetol 22:197-205

Andersen JM, Skern-Mauritzen M, Boehme L, Wiersma YF, Rosing-Asvid A, Hammill MO, Stenson GB (2013) Investigating annual diving behaviour by hooded seals (Cystophora cristata) within the Northwest Atlantic Ocean. PLOS ONE 8:e80438

Araújo JN, Bundy A (2012) Effects of environmental change, fisheries and trophodynamics on the ecosystem of the western Scotian Shelf, Canada. Mar Ecol Prog Ser 464:51-67

Beauchamp J, Bouchard H, de Margerie P, Otis N, Savaria JY (2009) Recovery strategy for the blue whale (Balaenoptera musculus) Northwest Atlantic population in Canada. Species at Risk Act Recovery Strategy Series. Fisheries and Oceans Canada, Ottawa

Benjamins S, Ledwell W, Huntington J, Davidson AR (2012) Assessing changes in numbers and distribution of large whale entanglements in Newfoundland and Labrador, Canada. Mar Mamm Sci 28:579-601

Bombosch A, Zitterbarta D, Van Opzeelanda I, Frickenhausa S, Burkhardta E, Wiszc M, Boebel O (2014) Predictive habitat modelling of humpback (Megaptera novaeangliae) and Antarctic minke (Balaenoptera bonaerensis) whales in the Southern Ocean as a planning tool for seismic surveys. Deep Sea Res I 91:101-114

Breeze H, Fenton DG, Rutherford RJ, Silva MA (2002) The Scotian Shelf: an ecological overview for ocean planning. Can Tech Rep Fish Aquat Sci 2393:1-259

Buren AD, Koen-Alonso M, Pepin P, Mowbray F, Nakashima B, Stenson GB, Montevecchi WA (2014) Bottom-up regulation of capelin, a keystone forage species. PLOS ONE 9:e87589

Bystriakova N, Peregrym M, Erkens RHJ, Bezsmertna O, Schneider H (2012) Sampling bias in geographic and environmental space and its effect on the predictive power of species distribution models. Syst Biodivers 10:305-315

C-NLOPB (Canada-Newfoundland Offshore Petroleum Board) (2010) Seismic data coverage offshore Newfoundland and Labrador. Geophysical Data Coverage Offshore Newfoundland and Labrador, St. John's. www.cnlopb.ca

Cañadas A, Sagarminaga R, De Stephanis R, Urquiola E, Hammond PS (2005) Habitat preference modelling as a conservation tool: proposals for marine protected areas for cetaceans in southern Spanish waters. Aquat Conserv 15:495-521
Clark CW (1995) Application of US Navy underwater hydrophone arrays for scientific research on whales. Rep Int Whaling Comm 45:210-212

Compton RC (2004) Predicting key habitat and potential distribution of northern bottlenose whales (Hyperoodon ampullatus) in the northwest Atlantic Ocean. MSc thesis, University of Plymouth

COSEWIC (Committee on the Status of Endangered Wildlife in Canada) (2002) Assessment and update status report on the blue whale Balaenoptera musculus in Canada. Committee on the Status of Endangered Wildlife in Canada, Ottawa

COSEWIC (2011) Assessment and update status report on the northern bottlenose whale Hyperoodon ampullatus in Canada. Committee on the Status of Endangered Wildlife in Canada, Ottawa

Croll DA, Marinovic B, Benson S, Chavez FP, Black N, Ternullo R, Tershy BR (2005) From wind to whales: trophic links in a coastal upwelling system. Mar Ecol Prog Ser 289:117-130

*Dalebout ML, Hooker SK, Christensen I (2001) Genetic diversity and population structure among northern bottlenose whales, Hyperoodon ampullatus, in the western North Atlantic Ocean. Can J Zool 79:478-484

* Dalebout ML, Ruzzante DE, Whitehead H, Øien NI (2006) Nuclear and mitochondrial markers reveal distinctiveness of a small population of bottlenose whales (Hyperoodon ampullatus) in the western North Atlantic. Mol Ecol 15:3115-3129

* Devred E, Sathyendranath S, Platt T (2007) Delineation of ecological provinces using ocean colour radiometry. Mar Ecol Prog Ser 346:1-13

* Devred E, Sathyendranath S, Platt T (2009) Decadal changes in ecological provinces of the Northwest Atlantic Ocean revealed by satellite observations. Geophys Res Lett 36:1-6

DFO (Department of Fisheries and Oceans Canada) (1998) The Gully: a scientific review of its environment and ecosystem. Canadian Stock Assessment Secretariat, Dartmouth

DFO (2009) Recovery strategy for the northern bottlenose whale (Hyperoodon ampullatus), Scotian Shelf population, in Atlantic Canadian waters [Proposed]. Species at Risk Act Recovery Strategy Series, Department of Fisheries and Oceans Canada, Ottawa

DFO (2011) Recovery strategy for the northern and southern resident killer whales (Orcinus orca) in Canada. Species at Risk Act Recovery Strategy Series, Department of Fisheries and Oceans Canada, Ottawa

DFO (2014) Action plan for the northern bottlenose whale (Hyperoodon ampullatus), Scotian Shelf population, in Atlantic Canadian waters [Proposed]. Species at Risk Act Action Plan Series, Department of Fisheries and Oceans Canada, Ottawa

DFO (2015) Coral and sponge conservation strategy for eastern Canada 2015. www.dfo-mpo.gc.ca/oceans/publications /cs-ce/page03-eng.html (accessed 8 October 2016)

DFO (2016) Recovery strategy for the northern bottlenose whale (Hyperoodan ampullatus), Scotian Shelf population, in Atlantic Canadian Waters. Species at Risk Act Recovery Strategy Series, Department of Fisheries and Oceans Canada, Ottawa

* Di Iorio L, Clark CW (2010) Exposure to seismic survey alters blue whale acoustic communication. Biol Lett 6:51-54

* Doniol-Valcroze T, Berteaux V, Larouche P, Sears R (2007) Influence of thermal fronts on habitat selection by four rorqual whale species in the Gulf of St. Lawrence. Mar Ecol Prog Ser 335:207-216 
Elith J, Graham CH, Anderson RP, Dudík M, Ferrier S, Guisan A, Zimmermann NE (2006) Novel methods improve prediction of species' distributions from occurrence data. Ecography 29:129-151

Elith J, Phillips S, Hastie T, Dudík M, Chee YE, Yates CJ (2011) A statistical explanation of MaxEnt for ecologists. Divers Distrib 17:43-57

Etnoyer P, Canny D, Mate BR, Morgan LE, Ortega-Ortiz JG, Nichols WJ (2006) Sea-surface temperature gradients across blue whale and sea turtle foraging trajectories off the Baja California Peninsula, Mexico. Deep Sea Res II 53:340-358

Evans JS, Oakleaf J, Cushman SA, Theobald D (2014) An ArcGIS toolbox for surface gradient and geomorphometric modeling, version 2.0-0. http://evansmurphy.wix.com/ evansspatial (accessed 8 January 2016)

Fiedler PC, Reilly SB, Hewitt RP, Demer D and others (1998) Blue whale habitat and prey in the California Channel Islands. Deep Sea Res II 45:1781-1801

Fielding AH, Bell JF (1997) A review of methods for the assessment of prediction errors in conservation presence/absence models. Environ Conserv 24:38-49

Fithian W, Hastie T (2013) Finite-sample equivalence in statistical models for presence-only data. Ann Appl Stat 7: 1917-1939

Fogarty MJ, Murawski SA (1998) Large-scale disturbance and the structure of marine systems: fishery impacts on Georges Bank. Ecol Appl 8:S6-S22

Forney KA, Ferguson MC, Becker EA, Fiedler PC and others (2012) Habitat-based spatial models of cetacean density in the eastern Pacific Ocean. Endang Species Res 16: 113-133

F Fourcade Y, Engler JO, Rödder D, Secondi J (2014) Mapping species distributions with MAXENT using a geographically biased sample of presence data: a performance assessment of methods for correcting sampling bias. PLOS ONE 9:e97122

Fuentes-Yaco C, King M, Li WKW (2015) Mapping areas of high phytoplankton biomass in the offshore component of the Scotian Shelf bioregion: a remotely-sensed approach. Canadian Scientific Advisory Secretariat (CSAS) Research Document 2015/036. Department of Fisheries and Oceans Canada, Dartmouth

Gessler PE, Moore ID, McKenzie NJ, Ryan PJ (1995) Soillandscape modelling and spatial prediction of soil attributes. Int J Geogr Inf Sci 9:421-432

Golding N, Purse B (2016) Fast and flexible Bayesian species distribution modelling using Gaussian processes. Methods Ecol Evol 7:598-608

Gomez C, Moors-Murphy HB (2014) Assessing cetacean distribution in the Scotian Shelf bioregion using habitat suitability models. Can Tech Rep Fish Aquat Sci 3088: $1-49$

Government of Canada (2005) Order amending schedules 1 to 3 to the Species At Risk Act. Can Gaz, II 139:73-109. http://publications.gc.ca/gazette/archives/p2/2005/200501-26/pdf/g2-13902.pdf

Government of Canada (2006) Order amending schedules 1 to 3 to the Species At Risk Act. Can Gaz, II 140:262-278. www.registrelep-sararegistry.gc.ca/document/default_e. cfm?documentID=863 (accessed 8 October 2016)

Government of Canada (2010) Description of critical habitat of the northern bottlenose whale (Hyperoodon ampullatus), Scotian Shelf population, in the Gully Marine Protected Area. Can Gaz, I 144:2192-2193. www.registrelep-sara registry.gc.ca/virtual_sara/files/g1-14433_e.pdf (accessed 8 October 2016)
Government of Canada (2011) National framework for Canada's network of marine protected areas. Department of Fisheries and Oceans Canada, Ottawa

* Gowans S, Whitehead H (1995) Distribution and habitat partitioning by small odontocetes in the Gully, a submarine canyon on the Scotian Shelf. Can J Zool 73:1599-1608

*Gowans S, Dalebout ML, Hooker SK, Whitehead H (2000) Reliability of photographic and molecular techniques for sexing northern bottlenose whales (Hyperoodon ampullatus). Can J Zool 78:1224-1229

* Grant J, Volckaert F, Roberts-Regan DL (1987) Resuspendable organic matter in Nova Scotian Shelf and Slope sediments. Cont Shelf Res 7:1123-1138

*Gregr EJ (2011) Insights into North Pacific right whale Eubalaena japonica habitat from historic whaling records. Endang Species Res 15:223-239

Gregr EJ, Trites AW (2001) Predictions of critical habitat for five whale species in the waters of coastal British Columbia. Can J Fish Aquat Sci 58:1265-1285

*Han G, Kulka DW (2009) Dispersion of eggs, larvae and pelagic juveniles of white hake (Urophycis tenuis) in relation to ocean currents of the Grand Bank: a modelling approach. J Northwest Atl Fish Sci 41:183-196

* Harris P, McMillan-Lawler M, Rupp J, Baker E (2014) Geomorphology of the oceans. Mar Geol 352:4-24

*Holt MM, Noren DP, Dunkin RC, Williams TM (2015) Vocal performance affects metabolic rate in dolphins: implications for animals communicating in noisy environments. J Exp Biol 218:1647-1654

Hooker SK, Whitehead H, Gowans S (1999) Marine protected area design and the spatial and temporal distribution of cetaceans in a submarine canyon. Conserv Biol 13:592-602

*Hooker SK, Cañadas A, Hyrenbach KD, Corrigan C, Polovina JJ, Reeves RR (2011) Making protected area networks effective for marine top predators. Endang Species Res 13:203-218

Horsman TL, Serdynska A, Zwanenburg KCT, Shackell NL (2011) Report on marine protected area network analysis for the Maritimes region of Canada. Can Tech Rep Fish Aquat Sci 2917:1-188

IOCCG (International Ocean-Colour Coordinating Group) (2000) Remote sensing of ocean colour in coastal, and other optically-complex, waters. In: Sathyendranath S (ed) Reports of the International Ocean-Colour Coordinating Group No. 3. IOCCG, Dartmouth

Jaquet N (1996) How spatial and temporal scales influence understanding of sperm whale distribution: a review. Mammal Rev 26:51-65

Kadmon R, Farber O, Danin A (2004) Effect of roadside bias on the accuracy of predictive maps produced by bioclimatic models. Ecol Appl 14:401-413

Kaschner K, Watson R, Trites AW, Pauly D (2006) Mapping world-wide distributions of marine mammal species using a relative environmental suitability (RES) model. Mar Ecol Prog Ser 316:285-310

Kaschner K, Quick NJ, Jewell R, Williams R, Harris CM (2012) Global coverage of cetacean line-transect surveys: status quo, data gaps and future challenges. PLOS ONE 7:e44075

Kenney R, Payne P, Heinemann D, Winn H (1996) Shifts in northeast shelf cetacean distributions relative to trends in Gulf of Maine/Georges Bank finfish abundance. In: Sherman K, Jaworski NA, Smayda TJ (eds) The northeast shelf ecosystem: assessment, sustainability, and management. Blackwell Science, Cambridge, MA, p 169-196 
King M, Shackell N, Greenlaw M, Allard K, Moors H, Fenton D (2013) Marine protected area network planning in the Scotian Shelf bioregion: offshore data considerations. Canadian Science Advisory Secretariat (CSAS) Research Document 2013/064. Department of Fisheries and Oceans Canada, Ottawa

Kobayashi DR, Cheng IJ, Parker DM, Polovina JJ, Kamezaki N, Balazs GH (2011) Loggerhead turtle (Caretta caretta) movement off the coast of Taiwan: characterization of a hotspot in the East China Sea and investigation of mesoscale eddies. ICES J Mar Sci 68:707-718

Lawson JW, Gosselin JF (2009) Distribution and preliminary abundance estimates for cetaceans seen during Canada's marine megafauna survey: a component of the 2007 TNASS. Canadian Science Advisory Secretariat Research Document 2009/031. Department of Fisheries and Oceans Canada, Ottawa

Lobo JM, Jiménez-Valverde A, Real R (2008) AUC: a misleading measure of the performance of predictive distribution models. Glob Ecol Biogeogr 17:145-151

Longhurst AR (2007) Ecological geography of the sea, 2nd edn. Academic Press, San Diego, CA

Lusseau D, Bain D, Williams R, Smith J (2009) Vessel traffic disrupts the foraging behavior of southern resident killer whales Orcinus orca. Endang Species Res 6:211-221

MacLeod CD, Santos MB, Pierce GJ (2003) Review of data on diets of beaked whales: evidence of niche separation and geographic segregation. J Mar Biol Assoc UK 83: 651-665

Mannocci L, Monestiez P, Spitz J, Ridoux V (2015) Extrapolating cetacean densities beyond surveyed regions: habitatbased predictions in the circumtropical belt. J Biogeogr 42:1267-1280

Margules CR, Pressey RL (2000) Systematic conservation planning. Nature 405:243-253

Marotte EC, Moors-Murphy H (2015) Seasonal occurrence of blue whale (Balaenoptera musculus) vocalizations in the Gully Marine Protected Area. Can Acoust 43(3) https://jcaa.caa-aca.ca/index.php/jcaa/article/view/2796

McKenna MF (2011) Blue whale response to underwater noise from commercial ships. PhD thesis, University of California, San Diego, CA

Melcón ML, Cummins AJ, Kerosky SM, Roche LK, Wiggins SM, Hildebrand JA (2012) Blue whales respond to anthropogenic noise. PLOS ONE 7:e32681

Merow C, Smith MJ, Silander JA (2013) A practical guide to MaxEnt for modeling species' distributions: what it does, and why inputs and settings matter. Ecography 36: 1058-1069

* Moore ID, Grayson RB, Ladson AR (1991) Digital terrain modelling: a review of hydrological, geomorphological, and biological applications. Hydrol Processes 5:3-30

Moors HB (2012) Acoustic monitoring of Scotian Shelf northern bottlenose whales (Hyperoodon ampullatus). $\mathrm{PhD}$ thesis, Dalhousie University, Halifax

*Moors-Murphy H (2014) Submarine canyons as important habitat for cetaceans, with special reference to The Gully: a review. Deep Sea Res II 104:6-19

Mora C, Sale PF (2011) Ongoing global biodiversity loss and the need to move beyond protected areas: a review of the technical and practical shortcomings of protected areas on land and sea. Mar Ecol Prog Ser 434:251-266

Morato T, Hoyle SD, Allain V, Nicol SJ (2010) Seamounts are hotspots of pelagic biodiversity in the open ocean. Proc Natl Acad Sci USA 107:9707-9711

Morel A, Prieur L (1977) Analysis of variations in ocean color. Limnol Oceanogr 22:709-722
NAFO (Northwest Atlantic Fisheries Organization) (2014) Report of the 7th meeting of the NAFO Scientific Council (SC) Working Group on Ecosystem Science and Assessment (WGESA). NAFO SCS Doc 14/023, Dartmouth

NMFS (National Marine Fisheries Service) (2005) Recovery plan for the North Atlantic Right whale (Eubalaena glacialis). National Marine Fisheries Service, Silver Spring, MD

Nowacek DP, Broker K, Donovan G, Gailey G and others (2013) Responsible practices for minimizing and monitoring environmental impacts of marine seismic surveys with an emphasis on marine mammals. Aquat Mamm 39: 356-377

Nowacek DP, Clark CW, Mann D, Miller PJO, Rosenbaum HC, Golden JS, Southall BL (2015) Marine seismic surveys and ocean noise: time for coordinated and prudent planning. Front Ecol Environ 13:378-386

\%'Brien K, Whitehead H (2013) Population analysis of Endangered northern bottlenose whales on the Scotian Shelf seven years after the establishment of a Marine Protected Area. Endang Species Res 21:273-284

*Palacios DM, Bograd SJ, Foley DG, Schwing FB (2006) Oceanographic characteristics of biological hot spots in the North Pacific: a remote sensing perspective. Deep Sea Res II 53:250-269

* Palialexis A, Georgakarakos S, Karakassis I, Valavanis V (2011) Prediction of marine species distribution from presence-absence acoustic data: comparing the fitting efficiency and the predictive capacity of conventional and novel distribution models. Hydrobiologia 670:241-266

* Pearson RG, Raxworthy CJ, Nakamura M, Townsend Peterson A (2007) Predicting species distributions from small numbers of occurrence records: a test case using cryptic geckos in Madagascar. J Biogeogr 34:102-117

Pendleton DE, Sullivan PJ, Brown MW, Cole TVN, Good CP, Mayo CA, Pershing AJ (2012) Weekly predictions of North Atlantic right whale Eubalaena glacialis habitat reveal influence of prey abundance and seasonality of habitat preferences. Endang Species Res 18:147-161

Pepin P, Maillet GL, Fraser S, Lane D, Shears T (2007) Biological and chemical oceanographic conditions on the Newfoundland and Labrador Shelf during 2006. Canadian Science Advisory Secretariat (CSAS) Research Document 2007/042. Department of Fisheries and Oceans Canada, St. John's

* Phillips SJ, Anderson RP, Schapire RE (2006) Maximum entropy modeling of species geographic distributions. Ecol Modell 190:231-259

* Pirotta E, Matthiopoulos J, MacKenzie M, Scott-Hayward L, Rendell L (2011) Modelling sperm whale habitat preference: a novel approach combining transect and follow data. Mar Ecol Prog Ser 436:257-272

* Pirotta E, Brookes KL, Graham IM, Thompson PM (2014) Variation in harbour porpoise activity in response to seismic survey noise. Biol Lett 10:20131090

Podesta GP, Browder JA, Hoey JJ (1993) Exploring the association between swordfish catch rates and thermal fronts on US longline grounds in the western North Atlantic. Cont Shelf Res 13:253-277

Quinn GP, Keough MJ (2002) Experimental design and data analysis for biologists. Cambridge University Press, Cambridge

* Reeves RR (2000) The value of sanctuaries, parks, and reserves (protected areas) as tools for conserving marine mammals. Marine Mammal Commission, Bethesda, MD. https://permanent.access.gpo.gov/lps50752/reevesreport. pdf (accessed 8 June 2016) 
Reeves RR, Mitchell E, Whitehead H (1993) Status of northern bottlenose whale, Hyperoodon ampullatus. Can Field Nat 107:490-508

Richardson WJ, Greene CR Jr, Malme CI, Thomson DH (1995) Marine mammals and noise. Academic Press, San Diego, CA

* Roberts JJ, Best BD, Mannocci L, Fujioka E and others (2016) Habitat-based cetacean density models for the US Atlantic and Gulf of Mexico. Sci Rep 6:22615

Robertson FC, Koski WR, Trites AW (2016) Behavioral responses affect distribution analyses of bowhead whales in the vicinity of seismic operations. Mar Ecol Prog Ser 549:243-262

SARA (Species at Risk Act) (2002) Canadian Species at Risk Act SC 2002 c 29: an Act respecting the protection of wildlife species at risk in Canada. http://laws-lois.justice. gc.ca/eng/acts/S-15.3/page-1.html (accessed 8 June 2016)

Schoenherr JR (1991) Blue whales feeding on high concentrations of euphausiids around Monterey Submarine Canyon. Can J Zool 69:583-594

Sears R, Calambokidis J (2002) Update COSEWIC status report on the blue whale Balaenoptera musculus in Canada. Committee on the Status of Endangered Wildlife in Canada, Ottawa

Sears R, Williamson JM, Wenzel FW, Bérubé M, Gendron D, Jones P (1990) Photographic identification of the blue whale (Balaenoptera musculus) in the Gulf of St. Lawrence, Canada. Rep Int Whal Comm Spec Issue 12: 335-342

Sharafi SM, White M, Burgman M (2012) Implementing comprehensiveness, adequacy and representativeness criteria (CAR) to indicate gaps in an existing reserve system: a case study from Victoria, Australia. Ecol Indic 18:342-352

Simard Y, Lavoie D (1999) The rich krill aggregation of the Saguenay-St. Lawrence Marine Park: hydroacoustic and geostatistical biomass estimates, structure, variability, and significance for whales. Can J Fish Aquat Sci 56: 1182-1197

Simard Y, Roy N, Giard S, Yayla M (2014) Canadian yearround shipping traffic atlas for 2013, Vol 1: East Coast marine waters. Can Tech Rep Fish Aquat Sci 3091:1-327

Therriault JC (ed) (1991) The Gulf of St. Lawrence: Small ocean or big estuary? Publ Spec Can Sci Halieut Aquat 113:1-359

Thompson PM, Hastie GD, Nedwell J, Barham R, Brookes KL, Cordes LS, McLean N (2013) Framework for assessing impacts of pile-driving noise from offshore wind farm construction on a harbour seal population. Environ Impact Assess Rev 43:73-85

Tittensor DP, Bac AR, Brewin PE, Clark MR, Consalvey M, Hall-Spencer J, Rogers AD (2009) Predicting global habitat suitability for stony corals on seamounts. J Biogeogr 36:1111-1128

* Tognelli MF, De Arellano PIR, Marquet PA (2008) How well do the existing and proposed reserve networks represent vertebrate species in Chile? Divers Distrib 14:148-158

Tognelli MF, Fernández M, Marquet PA (2009) Assessing the performance of the existing and proposed network of marine protected areas to conserve marine biodiversity in Chile. Biol Conserv 142:3147-3153

Tougaard J, Wright A, Madsen P (2015) Cetacean noise criteria revisited in the light of proposed exposure limits for harbour porpoises. Mar Pollut Bull 90:196-208

Vanderlaan ASM, Taggart CT (2009) Efficacy of a voluntary area to be avoided to reduce risk of lethal vessel strikes to endangered whales. Conserv Biol 23:1467-1474
Vanderlaan ASM, Smedbol K, Taggart C (2011) Fishinggear threat to right whales (Eubalaena glacialis) in Canadian waters and the risk of lethal entanglement. Can J Fish Aquat Sci 68:2174-2193

*Weimerskirch H (2007) Are seabirds foraging for unpredictable resources? Deep Sea Res II 54:211-223

Westhead M, King M, Herbert G (2013) Marine protected area network planning in the Scotian Shelf bioregion: context and conservation objectives. Canadian Science Advisory Secretariat (CSAS) Research Document 2012/126. Department of Fisheries and Oceans, Dartmouth

Whitehead H (2013) Trends in cetacean abundance in the Gully submarine canyon, 1988-2011, highlight a $21 \%$ per year increase in Sowerby's beaked whales (Mesoplodon bidens). Can J Zool 91:141-148

*Whitehead H, MacLeod CD, Rodhouse P (2003) Differences in niche breadth among some teuthivorous mesopelagic marine mammals. Mar Mamm Sci 19:400-406

Whitehead H, O'Brien K, Worm B (2010) Diversity of deepwater cetaceans and primary productivity. Mar Ecol Prog Ser 408:1-5

*Wiersma YF, Nudds TD (2009) Efficiency and effectiveness in representative reserve design in Canada: the contribution of existing protected areas. Biol Conserv 142: 1639-1646

Williams R, Lusseau D, Hammond P (2006) Estimating relative energetic costs of human disturbance to killer whales (Orcinus orca). Biol Conserv 133:301-311

*Williams R, Erbe C, Ashe E, Clark CW (2015a) Quiet(er) marine protected areas. Mar Pollut Bull 100:154-161

* Wimmer T, Whitehead H (2004) Movements and distribution of northern bottlenose whales, Hyperoodon ampullatus, on the Scotian Slope and in adjacent waters. Can J Zool 82:1782-1794

Wong SNP (2012) A pelagic paradox: the ecology of a top predator in an oceanic desert. PhD thesis, Dalhousie University, Halifax

* Worm B, Myers RA (2003) Meta-analysis of cod-shrimp interactions reveals top-down control in oceanic food webs. Ecology 84:162-173

*Worm B, Lotze HK, Myers RA (2003) Predator diversity hotspots in the blue ocean. Proc Natl Acad Sci USA 100: 9884-9888

Wright AJ (2014) Reducing impacts of noise from human activities on cetaceans: knowledge gap analysis and recommendations. WWF International, Gland. www.wwf.de/ fileadmin/fm-wwf/Publikationen-PDF/Report-ReducingImpacts-of-Noise-from-Human-Activities-on-Cetaceans. pdf (accessed 8 June 2016)

* Wright AJ, Kyhn LA (2015) Practical management of cumulative anthropogenic impacts with working marine examples. Conserv Biol 29:333-340

Fost AC, Petersen SL, Gregg M, Miller R (2008) Predictive modeling and mapping sage grouse (Centrocercus urophasianus) nesting habitat using maximum entropy and a long-term dataset from southern Oregon. Ecol Inform 3:375-386

* Zuur AF, Ieno EN, Elphick CS (2010) A protocol for data exploration to avoid common statistical problems. Methods Ecol Evol 1:3-14

Zwanenburg KCT, Bowen D, Bundy A, Drinkwater K and others (2002) Decadal changes in the Scotian Shelf large marine ecosystem. In: Skjoldal HR, Sherman K (eds) Large marine ecosystems of the North Atlantic - changing states and sustainability, Vol 10. Elsevier, Amsterdam, p 105-150

Submitted: June 10, 2016; Accepted: March 1, 2017

Proofs received from author(s): April 25, 2017 